\title{
Tephrostratigraphic studies on a sediment core from Lake Prespa in the Balkans
}

\author{
M. Damaschke ${ }^{1}$, R. Sulpizio ${ }^{2,3}$, G. Zanchetta ${ }^{4}$, B. Wagner ${ }^{1}$, A. Böhm ${ }^{1}$, N. Nowaczyk ${ }^{5}$, J. Rethemeyer ${ }^{1}$, and A. Hilgers ${ }^{6}$ \\ ${ }^{1}$ Institute of Geology and Mineralogy, University of Cologne, Zülpicher Straße 49a, 50674 Cologne, Germany \\ ${ }^{2}$ Dipartimento di Scienze della Terra e Geoambientali, University of Bari, via Orabona 4, 70125 Bari, Italy \\ ${ }^{3}$ IDPA-CNR, via Mario Bianco 9, Milan, Italy \\ ${ }^{4}$ Dipartimento di Scienze della Terra, University of Pisa, via S. Maria 53, 56126 Pisa, Italy \\ ${ }^{5}$ German Research Centre for Geosciences GFZ, Section 5.2 - Climate dynamics and landscape evolution, \\ Telegrafenberg C321, 14473 Potsdam, Germany \\ ${ }^{6}$ Institute of Geography, University of Cologne, 50923 Cologne, Germany
}

Correspondence to: B. Wagner (wagnerb@uni-koeln.de)

Received: 10 August 2012 - Published in Clim. Past Discuss.: 12 September 2012

Revised: 18 December 2012 - Accepted: 18 December 2012 - Published: 30 January 2013

\begin{abstract}
A detailed tephrostratigraphic record, which dates back to Marine Isotope Stage (MIS) 5b (ca. $91 \mathrm{kyr}$ ), has been established from a $17.76 \mathrm{~m}$ long core (Co1215) from Lake Prespa (Macedonia, Albania and Greece). A total of eleven tephra and cryptotephra layers (PT0915-1 to PT091511) were identified, using XRF scanning, magnetic susceptibility measurements, and macro- and microscopic inspection of the sediments. The major element composition of glass shards and/or micro-pumice fragments indicates that the tephras and cryptotephras originate from the explosive volcanism of Italy. Eight tephra and cryptotephra layers were correlated with specific volcanic eruptions: the AD 512 eruption of Somma-Vesuvius ( 1438 cal yr BP), the Mercato eruption of Somma-Vesuvius ( $8890 \pm 90$ cal yr BP), the Tufi Biancastri/LN1-LN2 eruption of the Campi Flegrei $(14749 \pm 523 \mathrm{cal} \mathrm{yr} \mathrm{BP}$ and $15551 \pm 621 \mathrm{cal} \mathrm{yr} \mathrm{BP})$, the SMP1-e/Y-3 eruption of the Campi Flegrei (3000031000 cal yr BP), the Campanian Ignimbrite/Y-5 eruption of the Campi Flegrei $(39280 \pm 110$ cal yr BP), the SMP1a event of Ischia Island (around $44000 \mathrm{cal} \mathrm{yr} \mathrm{BP)} \mathrm{and}$ the Green Tuff/Y-6 eruption of Pantelleria Island (around $45000 \mathrm{cal}$ yr BP). One tephra could be attributed to the volcanic activity of Mount Etna, but probably represents an unknown eruption at ca. $60000 \mathrm{cal}$ yr BP. Cryptotephras PT0915-6 and PT0915-10 remain unclassified so far, but according to the presented age-depth model these would have been deposited around 35000 and $48500 \mathrm{cal}$ yr BP,
\end{abstract}

respectively. Some of the tephras and cryptotephras are recognised for the first time in the Balkan region. The tephrostratigraphic work provides important information about ash dispersal and explosion patterns of source volcanoes and can be used to correlate and date geographically distant paleoenvironmental and archaeological archives in the central Mediterranean region. Moreover, the tephrostratigraphic work in combination with radiocarbon and electron spin resonance (ESR) dating is a precondition for paleoclimatic reconstructions inferred from the sediment succession Co1215.

\section{Introduction}

Distal tephra layers represent individual time marker horizons in terrestrial and marine sediment successions, which have been used to establish an independent event stratigraphy for the Late Pleistocene and Holocene across the Mediterranean (e.g., Keller et al., 1978; Paterne et al., 1988; Calanchi et al., 1998; Narcisi and Vezzoli, 1999; St. Seymour et al., 2004; Wulf et al., 2004). This is an important precondition for paleoclimatic studies and for the generation of ash dispersal maps, which improve the understanding of the explosive history of source volcanoes. Further, it enables to link archaeological records to the environmental context. This is noteworthy since some groups of Homo sapiens sapiens 


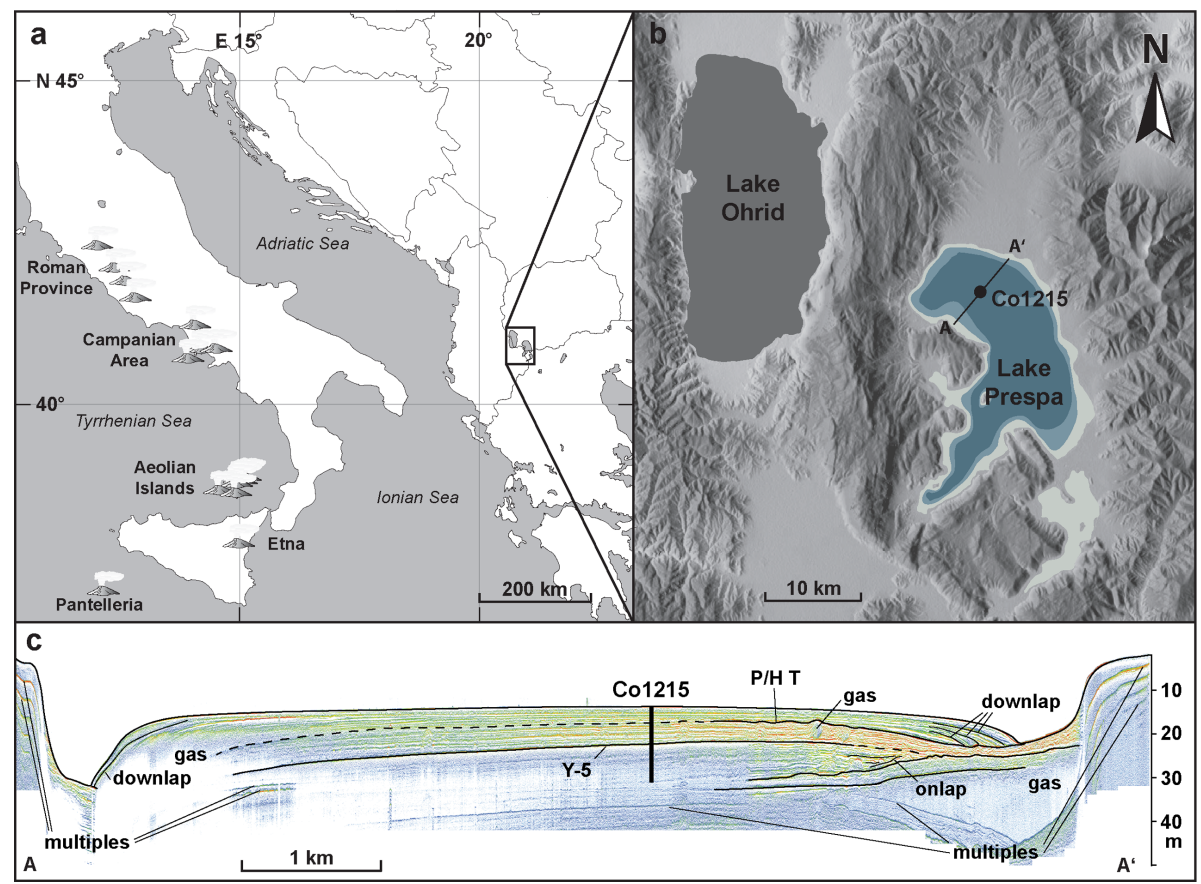

Fig. 1. (a) Map showing the location of Lake Prespa in the northeastern Mediterranean region and the distribution of Quaternary Italian volcanoes, (b) map showing the coring location of core Co1215, and (c) hydro-acoustic profile across the lake $\left(A-A^{\prime}\right)$ showing the coring location with recovery depth of Co1215, the Y-5 tephra and the Pleistocene/Holocene transition (P/HT) (modified after Wagner et al., 2012a).

first arrived during the Late Pleistocene in the Balkans (e.g., Trinkaus et al., 2003; Soficaru et al., 2006).

The Balkan Peninsula is considered to be a promising region for distal tephrostratigraphic studies in the Mediterranean region, as it is located ca. $600-800 \mathrm{~km}$ downwind of most Italian volcanoes which were active during the Late Quaternary (e.g., Peccerillo, 2005). In addition, the Balkan Peninsula hosts several ancient lakes (i.e., Ohrid, Prespa, Dojran, Shkodra), which have been shown to be good archives for distal tephra deposits (e.g., Wagner et al., 2008; Sulpizio et al., 2009; Caron et al., 2010; Vogel et al., 2010).

Already published tephrostratigraphic data from lakes Prespa and Ohrid is summarised by Sulpizio et al. (2010). Whilst the records from Lake Ohrid contain 10 tephras and cryptotephras for the last ca. 136000 cal yr BP, only 3 have been found in the last ca. $40000 \mathrm{cal} \mathrm{yr} \mathrm{BP}$ of Lake Prespa. The aim of this paper is to improve and extend the existing tephrostratigraphic record of Lake Prespa by investigating a $17.76 \mathrm{~m}$ long sediment core. For this purpose, highresolution X-ray fluorescence (XRF) scanning techniques combined with magnetic susceptibility (MS) measurements and macro- and microscopic screening of sediments were used to identify tephra and cryptotephra bearing horizons. Correlation of the tephras and cryptotephras to known eruptions, i.e., proximal and distal deposits, can improve the knowledge of the volcanic history in the central Mediterranean region and can unravel hitherto unknown eruptions.
It also can help to establish a reliable chronology for paleoenvironmental reconstructions based on Lake Prespa sediments, which is needed for a comparison of regional climate variations.

\section{Regional setting}

Lake Prespa $\left(40^{\circ} 46^{\prime}-41^{\circ} 00^{\prime} \mathrm{N}, 20^{\circ} 54^{\prime}-21^{\circ} 07^{\prime} \mathrm{E}\right)$ is located at an altitude of $844 \mathrm{~m}$ a.s.l. (above sea level) and shared between Macedonia, Albania and Greece (Fig. 1). It has a surface area of $254 \mathrm{~km}^{2}$, a maximum water depth of $48 \mathrm{~m}$ and a mean water depth of $14 \mathrm{~m}$. The catchment is ca. $1300 \mathrm{~km}^{2}$ and comprises the Baba Mountain Chain (2601 m a.s.1.) with metasediments and magmatites of Paleozoic and Mesozoic age to the east, and the Mali i Thatë Mountain Chain/Galiçica Mountain Chain (2250 ma.s.1.) with karstified limestone of Triassic age to the southwest and west (Geological Maps of Yugoslavia, 1977). The total inflow is ca. $16.9 \mathrm{~m}^{3} \mathrm{~s}^{-1}$, with $56 \%$ from river runoff, $35 \%$ from precipitation and $9 \%$ from Lake Mikri Prespa, a small lake connected with Lake Prespa through a man-made channel to the south (Matzinger et al., 2006). Lake Prespa has no natural surface outflow; water loss is trough evaporation (52\%), irrigation (2\%) and underground karst channels into Lake Ohrid (46\%), which is located $10 \mathrm{~km}$ to the west of Lake Prespa (Matzinger et al., 2006; Popovska and Bonacci, 2007). Both lakes remain mostly ice-free during winter (Wagner et al., 2010). 
Table 1. Radiocarbon dates from core Co1215, Lake Prespa, with depth, sample number, material, radiocarbon age and calendar age for each sample (modified after Wagner et al., 2012a). The radiocarbon ages were calibrated into calendar years before present (cal yr BP) with $2 \sigma$ ranges using CALIB Version 6.1.0 (Stuiver and Reimer, 2011). The uppermost sample (ETH-40050) from 0.04-0.06 m depth was calibrated using CALIBomb (Reimer et al., 2004) with the Levin.14c dataset (Levin and Kromer, 2004).

\begin{tabular}{lclll}
\hline Sample & $\begin{array}{c}\text { Depth } \\
(\mathrm{m})\end{array}$ & $\begin{array}{l}\text { Materia } \\
\text { (yr BP) }\end{array}$ & ${ }^{14}$ C Age & $\begin{array}{l}\text { Calendar Age } \\
\text { mean } \\
(\text { cal yr BP) }\end{array}$ \\
\hline ETH-40050 & $0.04-0.06$ & shell (Dreissena presbensis) & $-1190 \pm 30$ & $(-15) \pm 1$ \\
COL1030 & $0.42-0.44$ & plant (Carex sp.) & $715 \pm 28$ & $670 \pm 23$ \\
ETH-40051 & $0.74-0.76$ & plant (Phragmites australis) & $2080 \pm 35$ & $2065 \pm 80$ \\
ETH-40052 & $0.74-0.76$ & bulk organic matter & $3095 \pm 35$ & $3311 \pm 73$ \\
COL1031 & $1.04-1.06$ & bulk organic matter & $6003 \pm 28$ & $6854 \pm 77$ \\
ETH-40054 & $1.28-1.30$ & bulk organic matter & $7055 \pm 40$ & $7891 \pm 70$ \\
ETH-40055 & $1.46-1.47$ & bulk organic matter & $8205 \pm 40$ & $9155 \pm 127$ \\
ETH-40056 & $1.66-1.68$ & plant (Phragmites australis) & $8755 \pm 35$ & $9751 \pm 125$ \\
ETH-40057 & $1.66-1.68$ & bulk organic matter & $9090 \pm 35$ & $10242 \pm 50$ \\
ETH-40059 & $1.84-1.85$ & bulk organic matter & $9840 \pm 35$ & $11240 \pm 40$ \\
ETH-40060 & $2.12-2.14$ & fish remain & $10837 \pm 132$ & $12814 \pm 260$ \\
ETH-40062 & $2.14-2.16$ & fish remain & $11466 \pm 121$ & $13357 \pm 249$ \\
ETH-40063 & $2.14-2.16$ & bulk organic matter & $11005 \pm 40$ & $12887 \pm 187$ \\
COL1032 & $3.01-3.03$ & plant (aquatic) & $14056 \pm 71$ & $17159 \pm 301$ \\
ETH-40064 & $6.33-6.35$ & plant remains & $26345 \pm 105$ & $31009 \pm 202$ \\
ETH-40065 & $7.28-7.29$ & plant remains & $33075 \pm 210$ & $37760 \pm 808$ \\
\hline
\end{tabular}

\section{Material and methods}

Core Co1215 ( $\left.40^{\circ} 57^{\prime} 50^{\prime \prime} \mathrm{N}, 20^{\circ} 58^{\prime} 41^{\prime \prime} \mathrm{E}\right)$ was recovered in autumn 2009 and summer 2011 from the central-northern part of Lake Prespa. A seismic survey indicated an undisturbed sediment succession at the coring location (Fig. 1, Wagner et al., 2012a). Core recovery was performed from a floating platform, using a gravity corer for undisturbed surface sediments and a $3 \mathrm{~m}$ long percussion piston corer (UWITEC Co. Austria) for deeper sediments. Correlation of the individual core segments to a $17.76 \mathrm{~m}$ long composite core is described in detail in Wagner et al. (2012a).

High-resolution X-ray fluorescence (XRF) measurements were carried out using an ITRAX core scanner (COX Ltd) at the University of Cologne, with a Mo-tube set to $30 \mathrm{kV}$ and $30 \mathrm{~mA}$, and a Si-drift chamber detector. XRF scanning was performed in $2 \mathrm{~mm}$ steps with an analysis time of $10 \mathrm{~s}$ per measurement. Variations in heavy element counts $(\mathrm{Rb}, \mathrm{Sr})$ caused by variations in $\mathrm{X}$-ray source power and due to tube alternation were normalised for coherent scattering (Hoffmann, 2006). Magnetic susceptibility (MS) measurements were obtained every $1 \mathrm{~mm}$ using a Bartington MS2E spotreading sensor first attached to a MS2 control unit, integrated into a 2nd generation split-core logger (scl-2.3) designed at the Helmholtz Centre Potsdam GFZ. Total carbon (TC) and total inorganic carbon (TIC) were determined with a DIMATOC 200 (DIMATEC Co.). Total organic carbon (TOC) was calculated by the difference between TC and TIC.

Radiocarbon dating with accelerator mass spectrometry (AMS) was carried out by the Laboratory of Ion Beam
Physics at ETH Zurich, Switzerland. Selected material from thirteen horizons, comprising terrestrial and aquatic plant remains, fish bones, shell remains and bulk organic matter (Aufgebauer et al., 2012; Wagner et al., 2012a), were pretreated according to methods described by Rethemeyer et al. (2013). For this study all conventional radiocarbon ages were calibrated using CALIB 6.1.0 (Stuiver and Reimer, 2011), based on the INTCAL09 calibration curve (Reimer et al., 2009) and are reported in years before present (cal yr BP) with $2 \sigma$ ranges (Table 1). The uppermost sample (ETH40050) from 0.04-0.06 m depth was calibrated using CALIBomb (Reimer et al., 2004) with the Levin.14c dataset (Levin and Kromer, 2004). The radiocarbon ages obtained on bulk organic, fish, or aquatic plant remains can be up to ca. $1500 \mathrm{yr}$ too old due to a hard-water effect (Aufgebauer et al., 2012). A shell layer (Dreissena sp.) at $14.63-14.58 \mathrm{~m}$ depth was dated by electron spin resonance (ESR) at the Geochronological Laboratory of the Institute of Geography, University of Cologne. For dose rate calculation internal radionuclide contents of the shells were determined by ICP-MS analysis at the Institute of Geology and Mineralogy, University of Cologne, whereas for calculation of the external dose rate uranium, thorium and potassium contents of the surrounding bulk sediment were measured by high-resolution gamma-ray spectrometry at the VKTA-Laboratory (Nuclear Engeneering and Analytics Inc., Dresden) as well as at the Geochronological Laboratory in Cologne. A multiple aliquot additive dose protocol was used for equivalent dose determination based on multiple sub-samples which were irradiated 
using a ${ }^{60} \mathrm{Co}$-Source at the Centre of Nuclear Medicine at the University of Düsseldorf. Several specimens of Dreissena sp. shells were combined in order to obtain sufficient material for dating. In total three individual samples were analysed: sample K-5800 from the core segment from 2009 (14.63$14.58 \mathrm{~m}$ ), and K-5835 and K-5836 from the shell layer in $14.88-14.58 \mathrm{~m}$ in the core segment from 2011. ESR measurements were carried out using a Bruker ESP 300E X-band spectrometer at a frequency of $9.8 \mathrm{GHz}$, with a microwave power of $25.3 \mathrm{~mW}$ (Schellmann and Kelletat, 2001; Schellmann et al., 2008). The field modulation amplitude was $0.5 \mathrm{G}$ with centre field at $3495 \mathrm{G}$, scan width was $40 \mathrm{G}$, scan time $21 \mathrm{~s}$ and 5 scans in total. The equivalent dose was derived from the analysis of the dating signal at $g=2.0006 \pm 0.0001$ (Schellmann and Kelletat, 2001). A detailed explanation of the ESR dating method is given by Grün (1989), Schellmann and Kelletat (2001) and Schellmann et al. (2008). All relevant parameters for ESR age calculation are summarised in Tables 2 and 3.

Potential tephra layers were initially identified by visible inspection of the core halves. Non-visible tephra layers, i.e., cryptotephras, were identified based on suspicious horizons from XRF scanning and MS measurements or microscopic inspections of selected sediment sections. About $3 \mathrm{~g}$ of sediment from every $2 \mathrm{~cm}$ was pre-treated with hydrogen peroxide $(\sim 15 \%)$ to remove organic matter and subsequently washed and sieved at 125 and $40 \mu \mathrm{m}$. Samples with abundant glass shards, pumice or scoria fragments were mounted on epoxy resin beads. They were additionally polished to avoid compositional variations due to surface alternation processes. Major element analyses on at least 10 glass shards or pumice fragments were performed using an EDAXDX micro-analyser (EDS) mounted on a Philips SEM 515 at the University of Pisa. Operating conditions were adjusted at $20 \mathrm{kV}$ acceleration voltage, $100 \mathrm{~s}$ live counting, 10 $9 \mathrm{~A}^{\circ}$ beam current, beam diameter $200-500 \mathrm{~mm}$ and 2100 2400 shots per second, with ZAF correction (Z: atomic number; A: absorption; and F: fluorescence). The ZAF correction procedure does not include natural or synthetic standards for reference and requires the analyses normalisation at a given value, which is chosen at $100 \%$. Instrument calibration and performance are given by Marianelli and Sbrana (1998). Several trials for comparing the performance of the Pisa SEMEDS with wave dispersion spectroscopy (WDS) have been extensively discussed by Cioni et al. (1997), Marianelli and Sbrana (1998), Caron et al. (2010), Sulpizio et al. (2010) and Vogel et al. (2010).

Identified tephras and cryptotephras were named according to their origin (PT for Prespa Tephra), the year of core recovery (2009) and the last two identification digits of the core Co1215. The description of the tephras and cryptotephras is based on their macro- and microscopic features as well as on chemical composition. In order to classify chemical compositions of analysed glass shards and pumice fragments the total alkali vs. silica (TAS) diagram (Le Bas et al., 1986)
Table 2. Radionuclide contents of bulk sediment samples from three different core segments. All analysis was done by high-resolution gamma-ray spectrometry with samples 1 and 2 (core from 2011) measured at the Cologne lab., and sample 3 (core from 2009) analysed at the VKTA lab., Dresden. All errors represent the 1- $\sigma$ level. For dose rate calculation the mean values were used.

\begin{tabular}{lccc}
\hline Sample & $\mathrm{U}(\mathrm{ppm})$ & Th $(\mathrm{ppm})$ & $\mathrm{K}(\%)$ \\
\hline 1 & $3.59 \pm 0.19$ & $17.57 \pm 1.02$ & $2.37 \pm 0.09$ \\
2 & $3.53 \pm 0.19$ & $17.99 \pm 1.03$ & $2.38 \pm 0.09$ \\
3 & $3.80 \pm 0.40$ & $17.30 \pm 0.60$ & $2.30 \pm 0.07$ \\
\hline
\end{tabular}

was used. Microphotographs of the tephras and cryptotephras were taken using a Canon PowerShot G10 digital camera mounted on a stereomicroscope.

\section{Results}

\subsection{Lithostratigraphy}

Core Co1215 is comprised of three major lithofacies, which differ in colour, sediment structure, grain size, organic and carbonate content, element counts $(\mathrm{K}, \mathrm{Rb}, \mathrm{Sr})$ and amplitude of MS (Fig. 2).

The base of core Co1215 between 17.76-15.22 m depth is formed by lithofacies III, which is characterised by an olive-brown to brown colour and massive, probably bioturbated sediments. The grain size composition is dominated by clayey silt with a frequent occurrence of fine sand. TOC is relatively high (between $2-8 \mathrm{wt}$. \%), but varies distinctly throughout this lithofacies, with maxima at 17.56 and $16.38 \mathrm{~m}$ depth and minima at 16.58 and $16.08 \mathrm{~m}$ depth. The high organic content correlates with relatively low detrital clastic material (K). TIC is low $(<0.5 \mathrm{wt}$ \%), except of the horizon between 16.80-16.12 $\mathrm{m}$ depth, where distinct maxima occur (Fig. 2). Plant and shell remains are absent (Table 1).

The core section between $15.22-13.70 \mathrm{~m}$ depth is formed by lithofacies II. This lithofacies has a grey-olive to light brown colour and consists of massive, probably bioturbated sediments. The grain size composition is dominated by silt with a sporadic occurrence of coarse sand and gravel grains. TOC is low (1-3wt.\%), which corresponds with high $\mathrm{K}$. TIC is very low $(<0.1 \mathrm{wt} . \%)$, except of the horizon between 14.63-14.58 m depth, where shell fragments of Dreissena sp. were found. According to ESR dating, the shell fragments have a mean age $(n=3)$ of $73570 \pm 7740 \mathrm{yr}$ (Table 3$)$.

The core section between 13.70-10.66 m depth is formed by lithofacies I, which has a light to medium grey colour and is also massive in sediment structure. The grain size composition is dominated by clayey silt with the sporadic occurrence of coarse sand and gravel grains. TOC is very low $(<1.5$ wt. \%) throughout this horizon. TIC is also negligible, 
Table 3. Parameters for dose rate calculation, total dose rates, equivalent dose values and ESR ages. All errors represent the 1- $\sigma$ level.

\begin{tabular}{lcccrl}
\hline Lab. code & Depth $(\mathrm{m})$ & $\begin{array}{c}\mathrm{U}(\mathrm{ppm}) \\
\text { [shells, ICP-MS }]\end{array}$ & $\begin{array}{c}\text { Dose rate } \\
\left(\mathrm{Gy} \mathrm{kyr}^{-1, *}\right)\end{array}$ & $\begin{array}{r}\text { Equivalent dose } \\
(\mathrm{Gy})\end{array}$ & $\begin{array}{l}\text { ESR age } \\
(\mathrm{kyr})\end{array}$ \\
\hline K-5800 & $14.58-14.63$ & $0.08 \pm 0.01$ & $1.36 \pm 0.10$ & $100.2 \pm 11.2$ & $73.9 \pm 9.9$ \\
K-5835a & $14.70-14.88$ & $0.06 \pm 0.01$ & $1.36 \pm 0.10$ & $93.71 \pm 2.03$ & $68.9 \pm 5.1$ \\
K-5836a & $14.58-14.70$ & $0.06 \pm 0.01$ & $1.36 \pm 0.10$ & $114.41 \pm 6.73$ & $84.1 \pm 7.8$ \\
\hline
\end{tabular}

* Calculation of dose rates includes the following parameters and assumptions: alpha-efficiency value $0.10 \pm 0.02$, thickness before and after surface etching $0.82 / 0.75 \mathrm{~mm}$, an average water content of $47 \pm 4.7 \%$ (weight water/wet sediment), calculation of the cosmic dose contribution is based on the actual sampling depth including additional shielding through a water column.

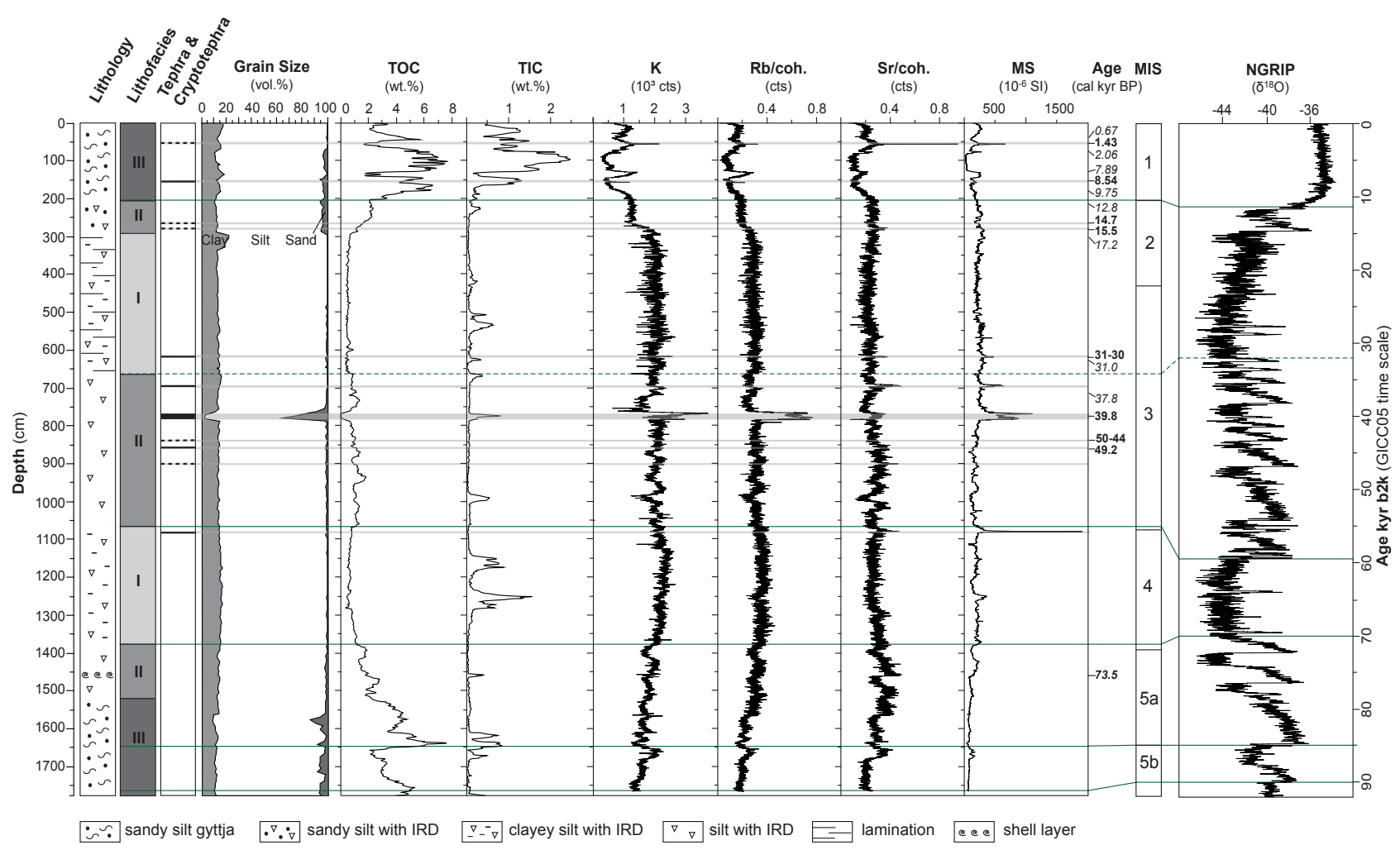

Fig. 2. Lithology, lithofacies, tephras and cryptotephras, grain size distribution, total organic carbon (TOC), total inorganic carbon (TIC), $\mathrm{K}, \mathrm{Rb}, \mathrm{Sr}$ counts from X-ray fluorescence (XRF) scanning with heavy element counts (Rb, Sr) normalised for coherent scattering (Hoffmann, 2006), magnetic susceptibility (MS), radiocarbon ages (italics), ESR mean age (italics and bold) and tephra/cryptotephra ages (bold) from core Co1215 in comparison with the marine isotope stages (MIS) 1-5 (Bassinot et al., 1994) and the oxygen isotope dataset from NGRIP (North Greenland Ice Core Project members, 2004) based on the Greenland Ice Core Chronology 2005 (GICC05) time scale (GICC05modelext, 2010 and references therein). GICC05 ages are given in units of b2k (years before 2000 AD). Green lines indicating tie points of core Co1215 with NGRIP-GICC05.

except of two maxima at 12.52 and $11.74 \mathrm{~m}$ depth. $\mathrm{K}$ is stable on a high level. MS has a distinct peak at $10.79 \mathrm{~m}$ depth. According to previous studies (Wagner et al., 2012a), this horizon was deposited during glacial times.

The core section between $10.66-6.62 \mathrm{~m}$ depth is formed by lithofacies II again, with up to $1.5 \mathrm{wt}$. \% TOC and generally very low TIC. A conspicuous horizon between 7.84-7.65 m depth is characterised by a relatively coarse grain-size composition, a more brownish colour, a minimum in TOC and maxima in TIC, $\mathrm{K}, \mathrm{Rb}$, and MS (Fig. 2). A radiocarbon age of a plant remain from $7.29 \mathrm{~m}$ depth indicates that this core section was deposited around $37000 \mathrm{cal} \mathrm{yr} \mathrm{BP} \mathrm{(Table} \mathrm{1).}$

The core section between $6.62-2.92 \mathrm{~m}$ depth is formed by lithofacies I again. However, in contrast to the lithofacies I section in the lower part of the core, the core section between $6.62-2.92 \mathrm{~m}$ depth indicates a distinct lamination, which is mainly due to the formation of concretionary horizons (Aufgebauer et al., 2012; Wagner et al., 2012a). 


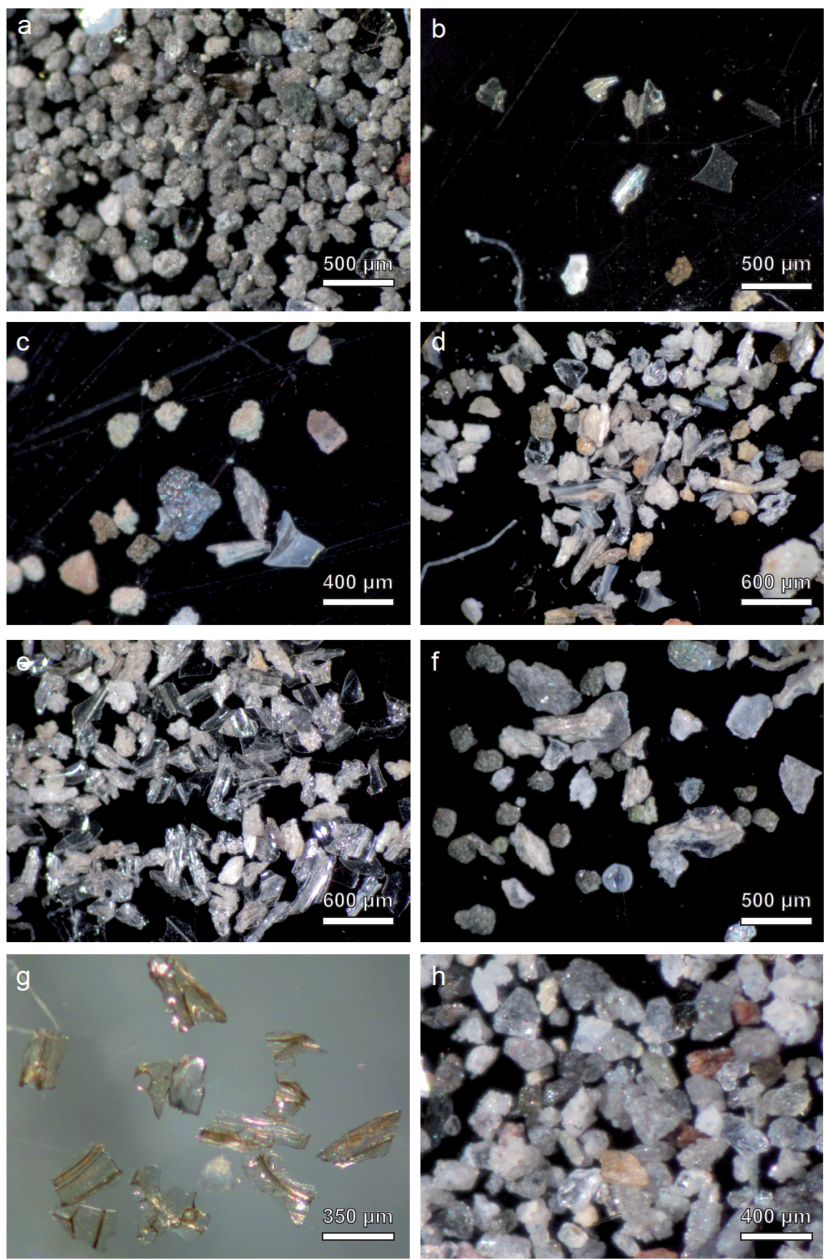

Fig. 3. Selected microphotograph of the investigated tephras and cryptotephras: (a) greenish to light brownish micro-pumice fragments of PT0915-1, (b) thin and transparent glass shards of PT0915-2, (c) white vesicular glass shard with sick septa of PT0915-3, (d) highly vesicular, white micro-pumice and white to brown glass shards of PT0915-5, (e) $100 \%$ transparent glass shards and highly vesicular micro-pumice of PT0915-7, (f) highly vesicular glass shards of PT0915-8, (g) transparent to light brown thick bubble-walled (partly Y-shaped) glass shards of PT0915-9, (h) scoria fragments with black phenocrysts of PT0915-11.

Radiocarbon ages of plant remains from 3.03 and $6.33 \mathrm{~m}$ depth (Table 1) indicate that this part of the core was deposited around the Last Glacial Maximum.

The core section between 2.92-2.04 m comprises sediments of lithofacies II again, but with a distinctly increased sand content. Radiocarbon ages from 2.16-2.12 m depth (Table 1) indicate a Late Pleistocene deposition of this core section.

The uppermost $2.04 \mathrm{~m}$ of core Co1215 are formed by lithofacies III. TOC and TIC vary distinctly, which is also indicated in clastic material and MS (Fig. 2). All radiocarbon ages from this section indicate Holocene ages (Table 1).

\subsection{Tephra and cryptotephra description}

Six tephra layers (visible by naked eye) and five cryptotephra layers (non-visible by naked eye) were recognised in core Co1215 (Table 4; Fig. 2). Exact thicknesses are only given for tephra layers, since cryptotephras did not form distinct horizons and are dispersed in the sediment. However, peaks in the MS or XRF data allow a rough estimation of the thickness of some cryptotephras.

Cryptotephra PT0915-1 (0.554-0.556 m depth) is characterised by peaks in MS, K, Rb and Sr values (Fig. 2), which span ca. $2 \mathrm{~mm}$. It is characterised by non-vesicular greenish to light brownish pumice fragments (Fig. 3). Plotted in the TAS diagram, it shows a main glass shard population with phonotephritic composition, a second population with tephriphonolitic composition, and rare glass shards with foiditic composition (Fig. 4a). The geochemical composition reveals very low silica contents $\left(\mathrm{SiO}_{2}<50 \mathrm{wt}\right.$. \%) and high $\mathrm{CaO}-$ contents ( $\mathrm{CaO}$ between 7 and 11 wt. \%) (Table 4).

Tephra PT0915-2 (1.556-1.562 $\mathrm{m}$ depth) is $6 \mathrm{~mm}$ thick and characterised by peaks in $\mathrm{K}$ and $\mathrm{Rb}$ values (Fig. 2), and by highly vesicular micro-pumice fragments and transparent glass shards. Micro-pumice fragments show spherical or elongate vesicles, whereas glass shards are completely glassy with thick septa or platy shape (Fig. 3). Tephra components have a maximum grain size of $400 \mu \mathrm{m}$. Tephra PT09152 indicates a fairly homogenous Na-phonolitic composition (Fig. 4b).

Cryptotephras PT0915-3 (2.650-2.670 m depth) and PT0915-4 (2.87-2.89 $\mathrm{m}$ depth) were recognised through microscopic analyses of washed and sieved sediments. PT09153 is more abundant in white highly vesicular micro-pumice fragments with elongate vesicles, whereas PT0915-4 comprises white vesicular glass shards with sick septa (Figs. 3 and 5). Tephra components have a maximum grain size of $400 \mu \mathrm{m}$. Both cryptotephras show an almost identical homogenous alkali-trachyte composition (Fig. 4c). Notable are high $\mathrm{SiO}_{2}$ (>60 wt. \%) and low $\mathrm{CaO}$ (about 2 wt. \%) contents. $\mathrm{MgO}$ contents are between $0.4-0.7$ wt. \% (Table 4).

Tephra PT0915-5 (6.168-6.178 m depth) shows peaks in $\mathrm{K}, \mathrm{Sr}$ and MS values (Fig. 2) and has a thickness of $1 \mathrm{~cm}$. It is abundant in highly vesicular, white micro-pumice and transparent, white to brown glass shards. Glass shards show mainly elongate pipe vesicles or conchoidal fractures (Fig. 3). The maximum grain size of tephra components is $600 \mu \mathrm{m}$. Glass chemistry is homogenous trachytic (Fig. 4d). Notable is the high potassic affinity $\left(\mathrm{K}_{2} \mathrm{O} \gg \mathrm{Na}_{2} \mathrm{O}\right.$; Table 4).

Tephra PT0915-6 (6.900-6.932 $\mathrm{m}$ depth) shows peaks in MS, Rb and Sr values (Fig. 2) and has a thickness of $3.2 \mathrm{~cm}$. Glass shards are rare and indicate a heterogeneous composition when plotted in the TAS diagram (Fig. 4e). Three compositional groups can be distinguished: (1) trachytes with $\mathrm{SiO}_{2}>60$ wt. \%, (2) latites with $55<\mathrm{SiO}_{2}<60$ wt. $\%$ and (3) shoshonites with $\mathrm{SiO}_{2}<55$ wt. $\%$ and high $\mathrm{Al}_{2} \mathrm{O}$ and $\mathrm{CaO}$ contents and a low alkali ratio of $\sim 1 \mathrm{wt}$. \% (Table 4 ). 


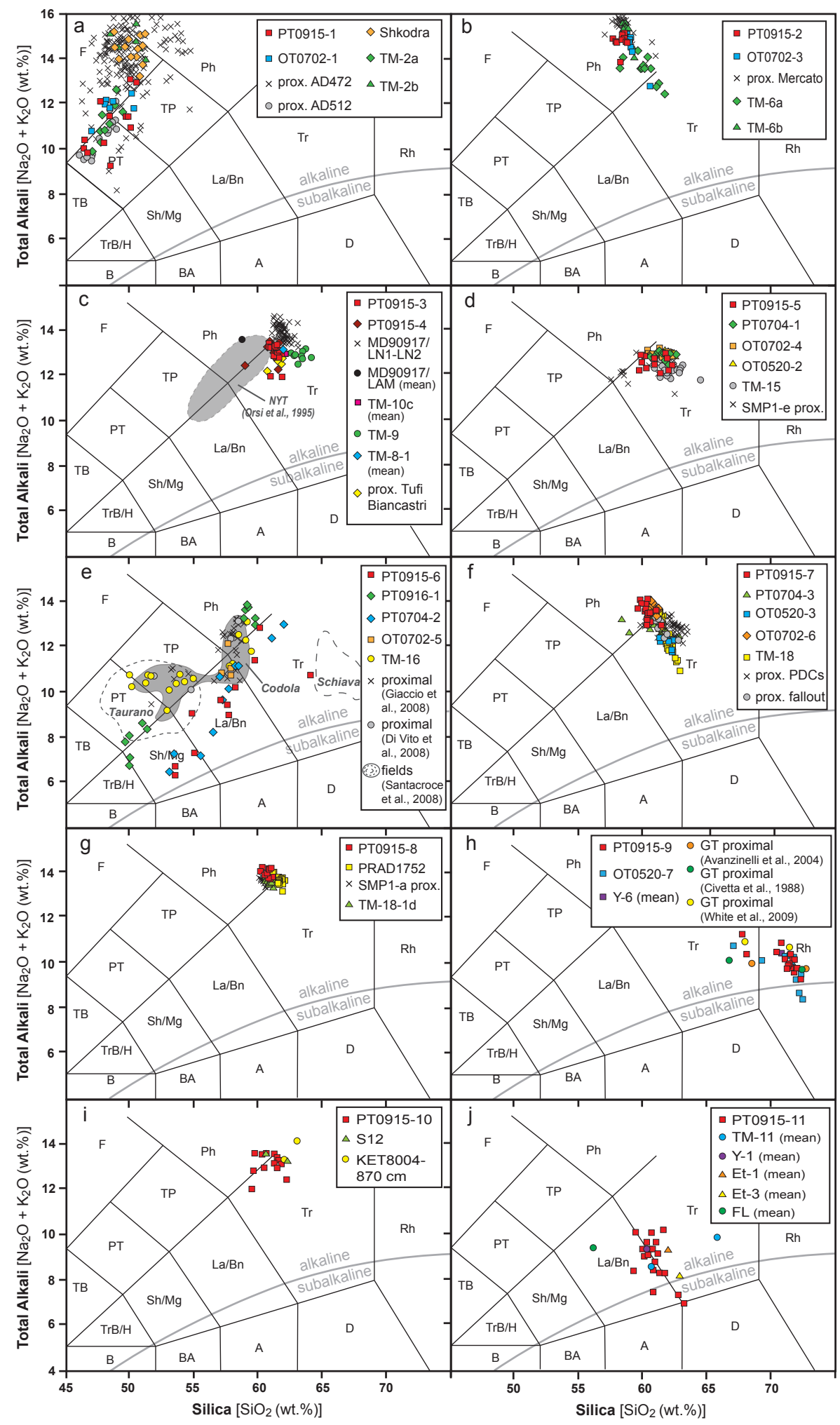

Fig. 4. Classification and correlation of tephras and cryptotephras recognised in core Co1215 from Lake Prespa (a-j) by means of the total alkali vs. silica diagram (TAS, Le Bas et al., 1986). The full set of raw data of tephras and cryptotephras identified in core Co1215 is given in Table 4 and Table S1 in the Supplement, and mean values of data used for correlation are summarised in Table S2 in the Supplement. 
Table 4. Average major element glass composition (normalised to $100 \%$ ) of investigated tephras and cryptotephras from Lake Prespa core Co1215. The full dataset is given in Table S1 in the Supplement.

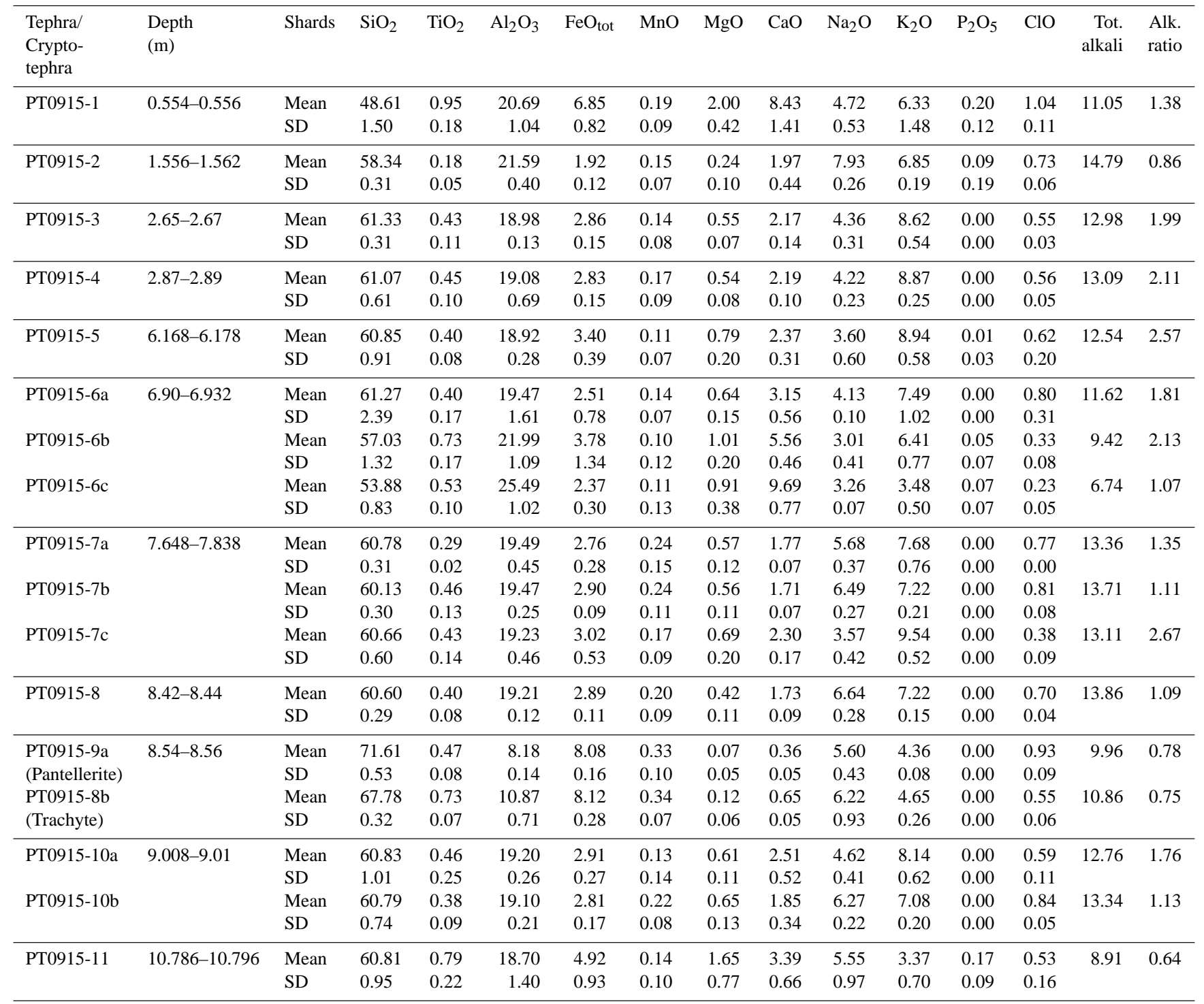

Tephra PT0915-7 (7.648-7.838 m depth) shows significant peaks in MS, K and $\mathrm{Rb}$ values (Fig. 2). The $19 \mathrm{~cm}$ thick layer is composed of almost $100 \%$ glass shards and micro-pumice. The glass shards are transparent to brown and have an elongated to platy shape, whereas micro-pumice fragments are highly vesicular (Fig. 3). Tephra components have a maximum grain size of $600 \mu \mathrm{m}$. The distinct bimodal glass composition ranges from trachytic to phonotrachytic (Fig. 4f).

Cryptotephra PT0915-8 (8.420-8.440 m depth), which has been identified microscopically, comprises transparent glass shards and some highly vesicular micro-pumice fragments. Glass shards have conchoid to irregular shapes and a maximum grain size of $500 \mu \mathrm{m}$ (Figs. 3 and 5). When plotted in the TAS diagram, the major glass composition is homogenous phonolitic with a slight shift towards the trachytic field (Fig. 4g). Notable is a very low alkali ratio around 1 wt. \% (Table 4).

Tephra PT0915-9 (8.540-8.560 m depth) does not indicate peaks in MS, $\mathrm{K}$ and $\mathrm{Rb}$ values (Fig. 2). It has been identified through macroscopic and microscopic inspection. The $2 \mathrm{~cm}$ thick tephra layer comprises transparent to light brown elongated and thick bubble-walled (partly Y-shaped) glass shards (Figs. 3 and 5) with a maximum grain size of $400 \mu \mathrm{m}$ and rhyolitic to trachytic composition (Fig. 4h). As the rhyolites of PT0915-9 have $\sim 71$ wt. $\% \mathrm{SiO}_{2}, \sim 8$ wt. $\% \mathrm{Al}_{2} \mathrm{O}_{3}$ and $7-$ 8 wt. $\% \mathrm{FeO}$ (Table 4), they can be classified as pantellerites (cf. Macdonald, 1974).

Cryptotephra PT0915-10 (9.008-9.010 m depth) has been identified by microscopic inspection and a minor peak in 

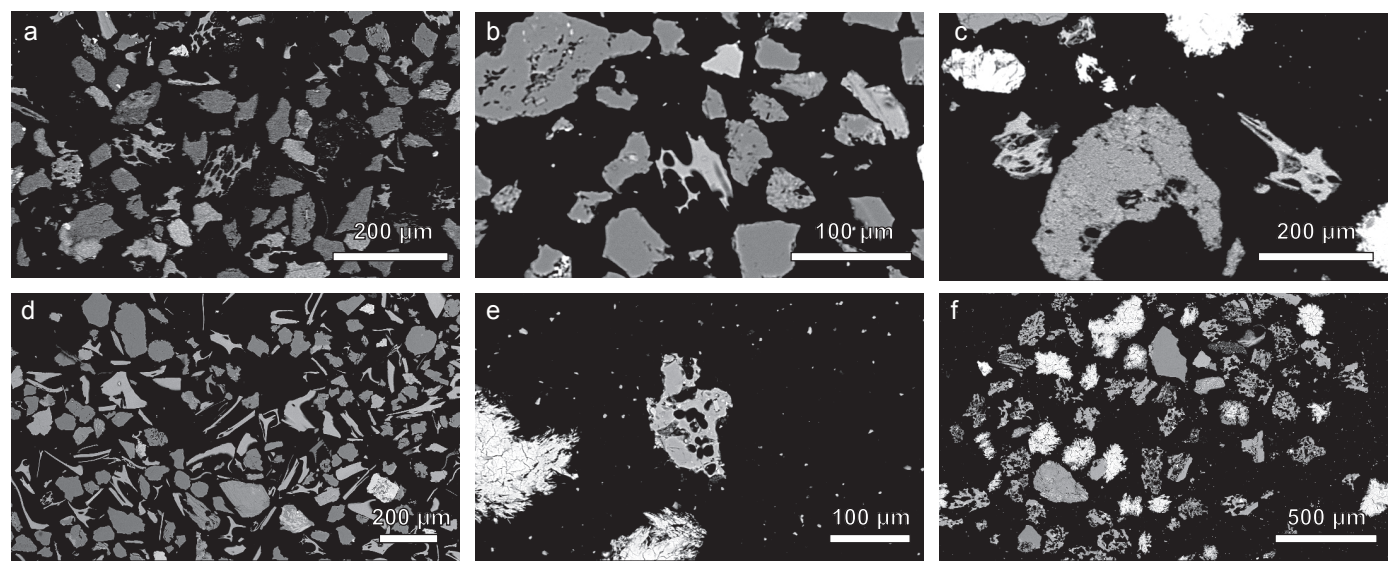

Fig. 5. Selected scanning electron microscope (SEM) photographs of the investigated tephras and cryptotephras: (a) vesicular micro-pumice fragments and glass shards of PT0915-3, (b) vesicular micro-pumice of PT0915-4, (c) highly vesicular glass shards of PT0915-8, (d) thickwalled (Y-shaped) glass shards of PT0915-9, (e-f) square phenocrysts in porphyritic scoria of PT0915-11.

Sr values. Glass shards are rare and poorly preserved. The glass composition is trachytic to phonolitic (Fig. 4i). Two geochemical groups can be defined, one with low alkali ratio $(<1.5$ wt. \%) and another one with high alkali ratio $(>1.5$ wt. \%) (Table 4).

Tephra PT0915-11 (10.786-10.796 m depth) shows a significant peak in MS, a minor peak in Sr values (Fig. 2), and spans $1 \mathrm{~cm}$. It comprises non-vesicular and blocky, light grey to grey scoria fragments with a porphyritic texture (Figs. 3 and 5). The glass composition ranges from trachyandesitic (benmoreitic) to trachytic (Fig. 4j). A high Na-affinity $\left(\mathrm{Na}_{2} \mathrm{O}>\mathrm{K}_{2} \mathrm{O}\right.$; Table 4$)$ is notable.

\section{Discussion and interpretation}

All tephras and cryptotephras in core Co1215 indicate alkaline affinity (Fig. 4). The only known source with mainly alkaline volcanism in the surrounding of Lake Prespa are the volcanic districts of the Italian Peninsula, which also would match with predominant westerly winds in the region. Volcanic products of the Aegean area (e.g., Greece, Santorini) and Central Anatolia (e.g., Turkey) show mainly calc-alkaline affinity (e.g., Keller et al., 1990; Druitt et al., 1995; Paterne et al., 2008) and those of Germany (Eifel volcanic district) and France (Massif Central) have never been recorded close to the study area (e.g., Van den Bogaard, 1995; Schmincke et al., 1999; Walter-Simonnet et al., 2008; Riede et al., 2011). Traces of the Vedde Ash from Iceland were recently found in the Lake Bled, Slovenia (Lane et al., 2011a), but not yet on the Balkan Peninsula. Two out of eleven tephras and cryptotephras (PT0915-9 and PT091511) are unambiguously correlated with the volcanic activities of Mount Etna and Pantelleria Island, reinforcing the hypothesis that Italian volcanoes are the sources of tephras and cryptotephras in core Co1215. The other 9 tephras and

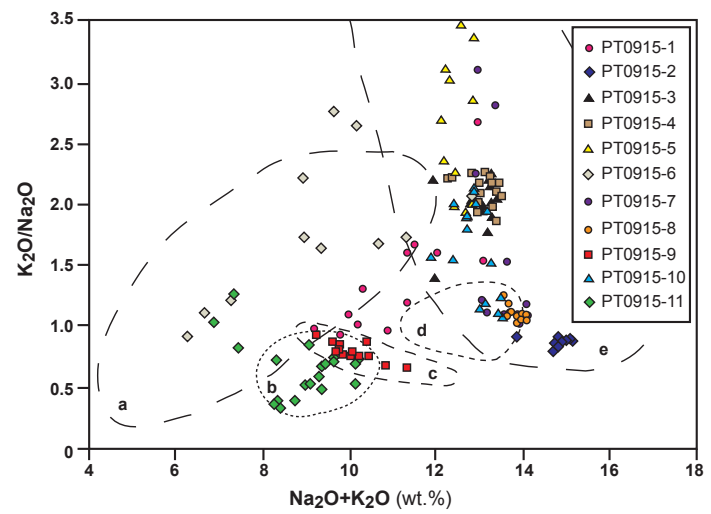

Fig. 6. $\mathrm{Na}_{2} \mathrm{O}+\mathrm{K}_{2} \mathrm{O}$ vs. $\mathrm{K}_{2} \mathrm{O} / \mathrm{Na}_{2} \mathrm{O}$ diagram (modified after Keller et al., 1978; Wulf, 2001; Calanchi and Dineli, 2008), showing the geochemical discrimination between the different volcanic provinces of Italy (dotted lines): (a) Aeolian Island, (b) Mount Etna, (c) Pantelleria Island, (d) Ischia Island, (e) Campanian Area (including Campi Flegrei and Somma Vesuvius) and investigated tephras and cryptotephras of core Co1215 from Lake Prespa.

cryptotephras in core Co1215 have a composition suggesting the Campanian area as most probable source (Fig. 6). However, the correlation of tephras and cryptotephras with proximal Campanian counterparts is very complex, because the geochemical composition can be similar among different volcanic sources (e.g., Campi Flegrei vs. Somma-Vesuvius, Sulpizio et al., 2003, 2010).

\subsection{PT0915-1/AD 512}

The foiditic to phonotephritic cryptotephra PT0915-1 is located between samples Col1030 and ETH-40051, which provide ages of $670 \pm 23 \mathrm{cal} \mathrm{yr} \mathrm{BP}$ and $2065 \pm 80 \mathrm{cal} \mathrm{yr} \mathrm{BP}$, respectively (Table 1). A well-known Mediterranean volcanic source producing undersaturated volcanic products during 
the Holocene is the Somma-Vesuvius (e.g., Ayuso et al., 1998; Santacroce et al., 2008). The composition of PT09151 overlaps the mafic "tail" of the $472 \mathrm{AD}$ (Pollena) eruption (Rosi and Santacroce, 1983) (Fig. 4a). Sulpizio et al. (2005) distinguished three main eruptive phases for the $472 \mathrm{AD}$ eruption. Only the climactic phase shows more mafic and less evolved composition, such as that found in PT0915-1. So far, distal deposits of the $472 \mathrm{AD}$ eruption have been detected in the sediments of Lake Shkodra (SK19; Sulpizio et al., 2009), Sulmona Basin (SUL1-5; Giaccio et al., 2009) and Lago Grande di Monticchio (TM-2a and TM-2b; Wulf et al., 2004). When plotted in the TAS-diagram (Fig. 4a), TM-2b and SK19 cluster well in the majority-field of $472 \mathrm{AD}$ proximal deposits, whereas the tephra TM-2a indicates a closer affinity to PT0915-1. Wulf et al. (2004) correlated the TM-2a with the $512 \mathrm{AD}$ eruption, a subplinian explosive event following the $472 \mathrm{AD}$ eruption (Cioni et al., 2011). In the Lake Ohrid sediments nearby, cryptotephra OT0702-1 has been assumed to be a mixture of the 472 and 512 AD eruptions (Vogel et al., 2010; Wagner et al., 2012b) and matches well with cryptotephra PT0915-1. As the sedimentation rate is similarly low in Lake Prespa, a mix of both eruption events in a single horizon rather than two distinct layers cannot be ruled out. For a better discrimination between both events, the geochemical compositions of proximal and distal deposits were plotted in the alkali vs. alkali ratio diagram (Fig. 7). Although the composition of AD 512 overlaps slightly the distribution field of 472 AD, PT0915-1 seems to indicate a better correlation with the $512 \mathrm{AD}$ proximal and TM-2a distal deposits. Therefore, PT0915-1 has been tentatively correlated to the 512 AD event (Santacroce et al., 2008; Cioni et al., 2011), even though the differentiation between the 472 and $512 \mathrm{AD}$ is difficult, because they have a very similar fingerprint and the information in historic records is rare. The recognition of $512 \mathrm{AD}$ volcanic products in the Balkan region significantly enlarges the area of tephra distribution to the east.

\subsection{PT0915-2/Mercato}

The microscopic characteristics and the distinctive homogenous phonolitic glass chemistry of tephra PT0915-2 suggest a correlation with the Mercato eruption from SommaVesuvius (e.g., Mele et al., 2011). The correlation is also supported by the stratigraphic position between the two radiocarbon samples ETH-40054 (7891 \pm 70 cal yr BP) and ETH40056 (9751 $\pm 125 \mathrm{cal} \mathrm{yr} \mathrm{BP)} \mathrm{(Table} \mathrm{1).} \mathrm{The} \mathrm{Mercato} \mathrm{erup-}$ tion was one of the largest plinian eruptions of SommaVesuvius (Santacroce et al., 2008). The fallout products were mainly dispersed towards the east and were recognised in several cores from the Adriatic Sea (Paterne et al., 1988; Lowe et al., 2007; Calanchi and Dinelli, 2008), in Lago Grande di Monticchio (TM-6 tephra, Wulf et al., 2004 and L4 tephra, Narcisi, 1996), and in cores from the Ionian Sea (Caron et al., 2008). According to the TAS diagram, the TM-6 tephra seems to cluster broader compared to tephra

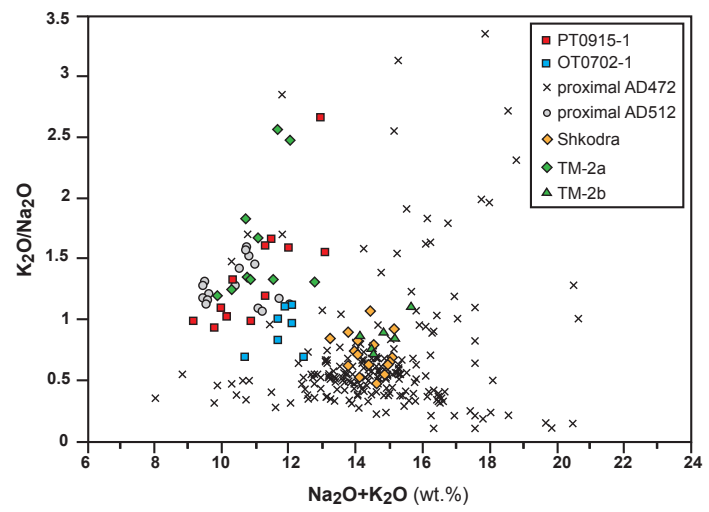

Fig. 7. $\mathrm{Na}_{2} \mathrm{O}+\mathrm{K}_{2} \mathrm{O}$ vs. $\mathrm{K}_{2} \mathrm{O} / \mathrm{Na}_{2} \mathrm{O}$ diagram showing the geochemical discrimination between the $472 \mathrm{AD}$ and $512 \mathrm{AD}$ eruption (proximal deposits; Santacroce et al., 2008; Table S2 in the Supplement). For comparison, data of distal deposits (Shkodra, Sulpizio et al., 2009; OT0702-1, Vogel et al., 2010; TM-2, Wulf et al., 2004; Table S2 in the Supplement) are also presented. Cryptotephra PT09151 favours correlation with $512 \mathrm{AD}$ and TM-2a.

PT0915-2 (Fig. 4b), which might be a result of multiple explosive phases of the Mercato eruption (Mele et al., 2011). Tephra layer TM-6 is split into TM-6-a at the top representing the final stage of the eruption and TM-6-b at the basal part, which has been correlated to the main phase of the Mercato eruption (Wulf et al., 2004). The latter tephra has a closer affinity to PT0915-2 from Lake Prespa. The Mercato tephra was also recognised in the sediment cores of the Island of Mljet, where it shows a bimodal composition similar to the Monticchio TM-6a and TM-6b tephras (Jahns and van den Bogaard, 1998). In Lake Ohrid, cryptotephra OT0702-3 indicated a similar phonolitic composition compared with tephra PT0915-2, and was also ascribed to the Mercato eruption (Vogel et al., 2010). Several radiocarbon ages are available for the Mercato eruption. Santacroce et al. (2008) reported an age of $8890 \pm 90 \mathrm{cal} \mathrm{yr} \mathrm{BP}$ obtained from soil organic fractions, while Zanchetta et al. (2011) provided an age of $8540 \pm 50$ cal yr BP obtained from charcoal below the proximal fallout deposits. The varve chronology of Lago Grande di Monticchio indicated an age of $9680 \pm 480 \mathrm{cal} \mathrm{yr}$ BP for the TM-6-b tephra layer (Wulf et al., 2004). The stratigraphic position of PT0915-2 ca. $10 \mathrm{~cm}$ above sample ETH-40056 $(9751 \pm 125 \mathrm{cal} \mathrm{yr} \mathrm{BP}$; Table 1$)$ and ca. $27 \mathrm{~cm}$ below sample ETH-40054 (7891 \pm 70 cal yr BP; Table 1) favours the age of $8890 \pm 90$ cal yr BP suggested by Santacroce et al. (2008), however, a precise chronological information for PT09152 cannot be given based on the radiocarbon ages in core Co1215.

\subsection{PT0915-3 and PT0915-4/LN1 and LN2 (Tufi Biancastri)}

The homogenous trachytic glass composition and strong K-affinity $\left(\mathrm{K}_{2} \mathrm{O} \gg \mathrm{Na}_{2} \mathrm{O}\right)$ of cryptotephras 
PT0915-3 and PT0915-4 suggest that they originate from the Campanian area (Fig. 6). The stratigraphic position of both cryptotephras between the radiocarbon samples ETH-40060 (12814 \pm 260 cal yr BP $)$, ETH-40062 (13357 \pm 249 cal yr BP), ETH-40063 $(12887 \pm 187 \mathrm{cal}$ yr BP $)$ and sample Col1032 (17 159 \pm 301 cal yr BP) (Table 1) implies a Late Pleistocene age. One of the largest eruptions in the considered time interval is the Neapolitan Yellow Tuff (NYT) eruption from the Campi Flegrei (Rosi and Sbrana, 1987), which occurred based on conventional radiocarbon measurements around $12300 \mathrm{yr}$ BP (uncalibrated; Alessio et al., 1971) and based on ${ }^{40} \mathrm{Ar} /{ }^{39} \mathrm{Ar}$ measurements at $14900 \mathrm{yr}$ (Deino et al., 2004). NYT products include a wide range of composition, which spans from phonolitic to trachytic and from latitic to tephriphonolitic (e.g., Orsi et al., 1992, 1995; Scarpati et al., 1993; Siani et al., 2004; Wulf et al., 2004). Since cryptotephras PT0915-3 and PT0915-4 do show homogenous trachytic glass composition and are found as two discrete layers suggesting two independent eruptions, a correlation with the NYT event is unlikely. This is supported by only marginal geochemical similarity with the more evolved part of NYT products (Figs. 4 and 8). Pre-NYT deposits were reported in proximal (e.g., Orsi et al., 1996; Pappalardo et al., 1999), medial (Di Vito et al., 2008) and distal areas (Siani et al., 2004; Wulf et al., 2004). The older products are highly evolved trachytes that become geochemically more similar to the less evolved NYT rocks with time (Pappalardo et al., 1999; Pabst et al., 2008). This transition is explained with magma withdrawal from a deep, trachytic parent magma chamber, which fed the pre-NYT eruptions and a three-layered NYT magma chamber erupted during the large NYT event.

Only a few tephra layers preceding the NYT-tephra were identified in distal sites so far. The oldest correspond to the Lagno Amendolare eruption $\left(15430 \pm 190 \mathrm{cal}{ }^{14} \mathrm{C} \mathrm{yr} \mathrm{BP}\right.$; Andronico, 1997) and are followed by those related to the Tufi Biancastri eruption $\left(14600 \pm 600{ }^{40} \mathrm{Ar} /{ }^{39} \mathrm{Ar} y r\right.$; Pappalardo et al., 1999; Zanchetta et al., 2000). Lagno Amendolare and Tufi Biancastri deposits were recognised in sediment records from the Adriatic Sea (core MD90917; LAM, LN1 and LN2, respectively; Siani et al., 2004) and in Lago Grande di Monticchio (TM-10 and TM-9, respectively; Wulf, 2001; Wulf et al., 2004, 2008).

When plotted in the $\mathrm{K}_{2} \mathrm{O}$ and $\mathrm{SiO}_{2}$ vs. $\mathrm{CaO}$ diagrams (Fig. 8), TM-10c seems to match the composition of PT09153 and PT0915-4 relatively well. The TM-10 tephra-sequence is dated between $15550 \pm 780$ and $15030 \pm 750 \mathrm{cal} \mathrm{yr} \mathrm{BP}$ (Wulf et al., 2008). The Lagno Amendolare tephra from the marine core, however, does not show any compositional similarity with PT0915-3 and PT0915-4. Nevertheless, the LN1 and LN2 tephras, which have been correlated with Tufi Biancasti, overlap well with the composition of PT09153 and PT0915-4 (Figs. 4 and 8). Radiocarbon dating provided ages of $12660 \pm 110 \mathrm{yr} \mathrm{BP}(14749 \pm 523 \mathrm{cal} \mathrm{yr} \mathrm{BP})$ and $12870 \pm 100 \mathrm{yr} \mathrm{BP}(15551 \pm 621$ cal yr BP $)$ for LN1 and LN2, respectively (Siani et al., 2004). In the Lago Grande di Monticchio succession TM-9 represents the lowermost tephra of Tufi Biancastri deposits (Wulf, 2001) and has a varve-supported age of $14560 \pm 730$ cal yr BP (Wulf, 2001; Wulf et al., 2004, 2008). Although cryptotephras PT0915-3 and PT0915-4 plot outside the majority field of TM-9 (Figs. 4 and 8), they are relatively similar with the uppermost tephra in this tephra unit, labelled as TM-8-1 (S. Wulf, personal communication, 2012). Due to these geochemical similarities, we tentatively correlate PT0915-3 and PT0915-4 with the late stage of the Tufi Biancastri eruption from the Campi Flegrei. As the ages for the LN1 and LN2 tephras provided by Siani et al. (2004) are in good agreement with ages given by Pappalardo et al. (1999), we propose that PT0915-3 has a best age of $14749 \pm 523 \mathrm{cal} \mathrm{yr} \mathrm{BP}$ and PT0915-4 has a best age of $15551 \pm 621 \mathrm{cal} \mathrm{yr} \mathrm{BP}$. Core Co1215 provides the first recognition of Tufi Biancastri products in the Balkan area and greatly enlarges their area of dispersal to the east.

\subsection{PT0915-5/Y-3}

The distinct homogenous alkali-trachytic composition of tephra PT0915-5 and the stratigraphic position above a radiocarbon dated plant remain at $6.35 \mathrm{~m}$ depth (ETH-40064; $31009 \pm 202$ cal yr BP; Table 1) suggest a correlation with the Y-3 tephra (Keller et al., 1978; Zanchetta et al., 2008). The most probable proximal counterpart for the Y-3 tephra is the SMP1-e eruption from the Campi Flegrei (Di Vito et al., 2008; Zanchetta et al., 2008). PT0915-5 overlaps well with the composition of SMP1-e proximal deposits (Fig. 4d). Radiocarbon dates achieved from charcoals underlying the proximal fallout deposits of SMP1-e suggest a maximum age of $30670 \pm 230$ cal yr BP (Di Vito et al., 2008), which is in good agreement with a ${ }^{40} \mathrm{Ar} /{ }^{39} \mathrm{Ar}$ age obtained on sanidine crystals from proximal deposits $(30300 \pm 200 \mathrm{yr}$; Pappalardo et al., 1999). Wulf et al. (2004) correlated the TM-15 tephra in the Lago Grande di Monticchio succession with the Y-3 tephra and suggested a varve-supported age of $27260 \mathrm{cal} \mathrm{yr} \mathrm{BP} \mathrm{(Wulf} \mathrm{et} \mathrm{al.,} \mathrm{2006).} \mathrm{Zanchetta} \mathrm{et}$ al. (2008) proposed a most probable age range between $30000-31000$ cal yr BP, which corresponds well with the stratigraphic position of PT0915-5 in relation to the radiocarbon age of sample ETH-40064 (Table 1).

The recognition of the Y-3 tephra in core Co1215 confirms previous findings from the north-western part of Lake Prespa (PT0704-1, Wagner et al., 2010) and in Lake Ohrid (OT05202, Wagner et al., 2008; JO-187, Caron et al., 2010; OT07001, Lindhorst et al., 2010; OT0702-4, Vogel et al., 2010).

\subsection{PT0915-6/Unknown}

Tephra PT0915-6 shows a similar compositional trend as cryptotephra PT0704-2, which was previously identified in core Co1204 from Lake Prespa (Sulpizio et al., 2010; Wagner 


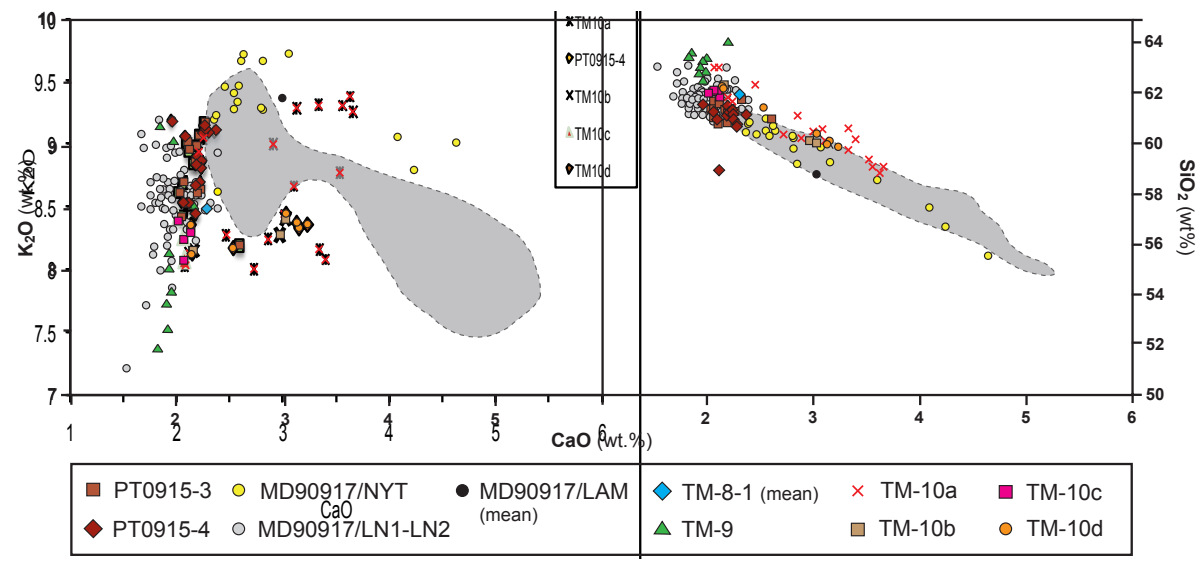

Fig. 8. $\mathrm{K}_{2} \mathrm{O}$ vs. $\mathrm{CaO}$ and $\mathrm{SiO}_{2}$ vs. $\mathrm{CaO}$ diagrams (modified after Pabst et al., 2008) showing the geochemical discrimination between NYT and pre-NYT deposits (dotted lines - NYT, Orsi et al., 1995; TM-8-1, Wulf, personal communication, 2012; TM-9, Wulf et al., 2004; TM10a-d, Wulf et al., 2004, 2008; LAM, LN1-LN2 and NYT, Siani et al., 2004; Table S2 in the Supplement) and investigated cryptotephras PT0915-3 and PT0915-4. Both favour correlation with pre-NYT deposits.

et al., 2010). Wagner et al. (2010) correlated PT0704-2 tentatively with the Codola eruption $(\sim 33000$ cal yr BP; Giaccio et al., 2008), while Sulpizio et al. (2010) proposed correlation with the activity of Vulcano (Aeolian Island), even though he cannot link the tephra to a specific eruption. A correlation of PT0915-6 with the volcanic activity of Vulcano (Aeolian Island) is possible according to the alkali vs. alkali ratio (Fig. 6). The stratigraphic position of tephra PT0915-6 below the Y-3 tephra (suggesting > 30000 $31000 \mathrm{cal} \mathrm{yr} \mathrm{BP}$ ) and between the radiocarbon ages of samples ETH-40064 (31 $009 \pm 202$ cal yr BP, Table 1) and ETH40065 (37 $760 \pm 808$ cal yr BP, Table 1) suggests a correlation with the widespread Codola eruption. The most reliable age for the Codola eruption comes from radiocarbon dating of foraminifera directly below the Codola tephra in a marine core from the Tyrrhenian Sea $(34270 \pm 870$ cal yr BP; Paterne et al., 1999), which agrees with the age window suggested by Giaccio et al. (2008). However, PT0915-6 partly shows a different compositional trend compared to proximal (e.g., Di Vito et al., 2008; Giaccio et al., 2008; Santacroce et al., 2008) and most distal (e.g., TM-16, Wulf et al., 2004; OT0702-5, Vogel et al., 2010) deposits, which are correlated with Codola (Fig. 4e). This could be explained by a lack of information, i.e., origin, dynamics, dispersal, and composition of Codola (e.g., Santacroce, 1987; Sulpizio et al., 2003; Di Vito et al., 2008; Giaccio et al., 2008; Santacroce et al., 2008). Considering the time interval, other potential sources for PT0915-6 are the eruptions of Schiava (Di Vito et al., 2008) and Taurano (Santacroce et al., 2008). Taurano was supposed to be one potential source of cryptotephra PT0916-1, which was found in a core from the lateral part of Lake Prespa (Sulpizio et al., 2010). However, the products of Schiava and Taurano have significantly different geochemical fingerprints compared with PT0915-6 (Fig. 4e), which makes their correlation unlikely. Due to the lack of unambiguous correlation with known eruptions, the source of cryptotephra of PT0915-6 cannot be clearly defined so far.

\subsection{PT0915-7/Y-5}

The trachytic to phonotrachytic glass composition and the alkaline affinity indicates that the Campanian area is the source of tephra layer PT0915-7 (Fig. 6). Moreover, the thickness of PT0915-7 $(19 \mathrm{~cm})$ and the trimodal composition of glass shards are particular fingerprints of the well-known Campanian Ignimbrite (CI) eruption from the Campi Flegrei (e.g., Orsi et al., 1996; Civetta et al., 1997; Giaccio et al., 2008). The CI eruption is one of the largest explosive eruptions of the Mediterranean region (Pyle et al., 2006) and can be sub-divided into an early phase with the most-evolved deposits and a final phase related to the caldera collapse with less-evolved deposits (e.g., Civetta et al., 1997; Pappalardo et al., 1999). The different eruptive phases comprised different zones of a strongly zoned trachytic magma chamber (Fedele et al., 2007), which is seen in three different alkali ratios (Table 4). The CI eruption was correlated with the distal tephra layer Y-5 in cores from the Tyrrhenian and Ionian Seas (Keller et al., 1978; Paterne et al., 1988), the TM-18 tephra layer in Lago Grande di Monticchio (Wulf et al., 2004), and with tephras from Lake Prespa (PT07043; Wagner et al., 2010) and Lake Ohrid (OT0520-3; Wagner et al., 2008, OT0702-6; Vogel et al., 2010). According to the Lago Grande di Monticchio varve chronology, the Y5/TM-18 deposits have an age of 36770 cal yr BP (Wulf et al., 2006). $\operatorname{Laser}{ }^{40} \mathrm{Ar} /{ }^{39} \mathrm{Ar}$ technique on single sanidine crystals proposed ages of $37100 \pm 400 \mathrm{yr}$ (Deino et al., 1994) and $41200 \pm 2100 \mathrm{yr}$ (Ton-That et al., 2001). The most accurate age of the $\mathrm{CI} / \mathrm{Y}-5$ eruption is based on a single crystal ${ }^{40} \mathrm{Ar} /{ }^{39} \mathrm{Ar}$ dating of proximal deposits $(39280 \pm 110 \mathrm{yr} \mathrm{BP}$, De Vivo et al., 2001). 
The Y-5 tephra is the most significant tephra in the central Mediterranean region and extends further to the east and northeast up into Russia (Pyle et al., 2006; Fedele et al., 2008; Giaccio et al., 2008; Fig. 9). It has been used as a major chrono-stratigraphic marker for the Upper Pleistocene (e.g., Narcisi, 1996; St. Seymour et al., 2004) and the onset of Heinrich event 4 (Ton That et al., 2001; Giaccio et al., 2006) in paleoclimatic and archeological studies.

\subsection{PT0915-8/SMP1-a}

The distinct homogenous trachyphonolitic composition of cryptotephra PT0915-8 indicates the Campanian area, particularly Ischia Island as its source (Fig. 6). Very few descriptions of pre-CI proximal deposits exist (Di Vito et al., 2008), which range in composition from phonolitic to trachytic (Pappalardo et al., 1999). Di Vito et al. (2008) described one proximal fallout deposit termed as SMP1-a, which was recovered on the Sorrentina Peninsula. PT0915-8 and proximal SMP1-a deposits match notably well in the geochemical characteristics (Fig. 4g). SMP1-a products are phonolitic, straddle the trachytic field and show an alkali ratio around 1, which would argue for an origin from Ischia Island (Poli et al., 1987; Crisci et al., 1989). Distal SMP1-a products have been found in sediment cores from the Tyrrhenian and Adriatic Seas (C14, Paterne et al., 1988; Sulpizio et al., 2003; PRAD1752, Bourne et al., 2010) and in Lago Grande di Monticchio (TM-18-1d, Wulf et al., 2006). All match well with the geochemical characteristics of SMP1-a proximal deposits and PT0915-8 (Fig. 4g).

According to the Lago Grande di Monticchio varve chronology TM-18-1d has an age of $37360 \mathrm{cal} \mathrm{yr} \mathrm{BP}$ and was deposited only 590 years before the CI (Wulf et al., 2006). The relatively large distance between PT0915-7/Y-5 and PT0915-8 does not support the correlation of PT0915-8 with the TM-18-1d/SMP1-a eruption. However, according to Di Vito et al. (2008) the age of the SMP1-a eruption varies between $39000-51000 \mathrm{cal} \mathrm{yr} \mathrm{BP.}$

The recognition of the SMP1-a tephra in Lake Prespa is the first finding of the tephra in the Balkan region and the most distal occurrence of this tephra so far. The distance of about $600 \mathrm{~km}$ between Ischia Island and Lake Prespa suggests that the SMP1-a eruption was probably of high magnitude and ash dispersal occurred mainly to the east.

\subsection{PT0915-9/Y-6}

The distinct pantelleritic glass composition of tephra PT0915-9 indicates that the peralkaline volcano of Pantelleria Island is the source of this tephra, as this is the only known volcanic district in the Mediterranean region producing such a pantelleritic composition during the Late Quaternary (Mahood and Hildreth, 1986). Correlation of PT0915-9 to the widespread "green ignimbrite" eruption, also known as "Green Tuff" (Orsi and Sheridan, 1984) is obvious, because

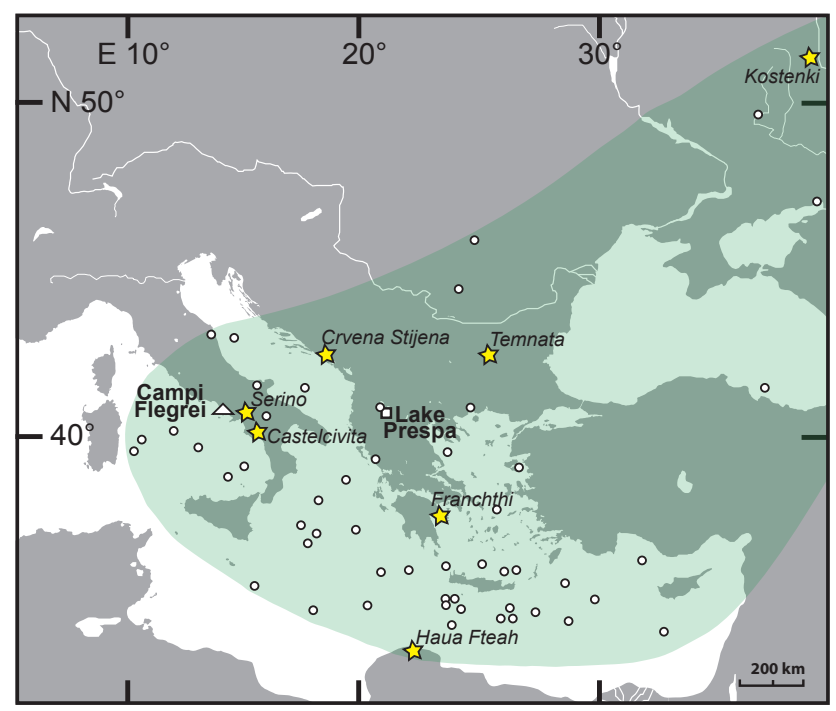

Fig. 9. Map showing the distribution of the Campanian Ignimbrite/Y5 tephra (green field), based on terrestrial/marine (white circles) and archaeological (yellow stars) sites; modified after Fedele et al. (2003, 2008). Archaeological sites refer to Vitaliano et al. (1981), Paterne (1992), Sinitsyn (2003), Giaccio et al. (2006), Lane et al. (2011b) and Morley and Woodward (2011).

their geochemical composition ranges from pantelleritic to trachytic (Civetta et al., 1988; Avanzinelli et al., 2004; White et al., 2009) (Fig. 4h). The "Green Tuff" has been correlated with the marine tephra layer Y-6 from Ionian Sea cores (Keller et al., 1978), which is commonly used as well-defined stratigraphic marker for the central Mediterranean region (e.g., Narcisi and Vezzoli, 1999). The Y-6 tephra was already identified in the Lake Ohrid record (OT0702-7, Vogel et al., 2010). Although the geochemical characteristics allow an unambiguous correlation of tephra PT0915-9 with the Green Tuff/Y-6 eruption, exact age assignments are lacking. According to K/Ar dating, ages between $50800 \pm 3600 \mathrm{yr}$ to $44500 \pm 3100$ yr (e.g., Cornette et al., 1983; Civetta et al., 1984; Mahood and Hildreth, 1986) are given, which are in good agreement with the interpolated stratigraphical age of ca. $45000 \mathrm{yr}$ BP for the marine marker tephra Y-6 (Keller et al., 1978).

The recognition of the Green Tuff/Y-6 deposits in both lakes suggests that the main ash distribution was towards the east.

\subsection{PT0915-10/Unknown}

The trachytic to phonolitic glass composition of cryptotephra PT0915-10 indicates that the Campanian area is its source (Fig. 6), however, as for PT0915-8, the correlation to a specific eruption is difficult, because only very few data exist on products erupted before the CI event (Orsi et al., 1996; Pappalardo et al., 1999). The alkali ratio and the distinct bimodal glass composition suggest that PT0915-10 can be correlated 
with the distal tephra S12 recovered from the San Gregorio Magno basin in southern Italy (Fig. 4i; Munno and Petrosino, 2007). The $S 12$ was correlated with an $87000 \mathrm{yr}$ old tephra in a core from the Tyrrhenian Sea (KET 8004, Paterne, 1985), much older than supposed by the stratigraphic position of PT0915-10 only $46 \mathrm{~cm}$ below the Green Tuff/Y-6 tephra and well above the ESR-dated horizon with a mean age of $73570 \pm 7740 \mathrm{yr}$ (Table 1). As there is no lithological indication for a hiatus in core Co1215 from Lake Prespa (Wagner et al., 2012a), the correlation of PT0915-10 with the S12 tephra is questionable. In the estimated time frame there are numerous tephra layers in the Lago Grande di Monticchio record with similar composition as PT0915-10 (S. Wulf, personal communication, 2012). However, the poorly preserved and rare glass shard content of PT0915-10 does not allow for an unambiguous correlation with the known regional tephra deposits at present.

\subsection{PT0915-11/Etna}

The benmoreitic composition and the Na-affinity $\left(\mathrm{Na}_{2} \mathrm{O} \gg \mathrm{K}_{2} \mathrm{O}\right)$ of tephra PT0915-11 is a typical chemical imprint of the volcanic activity of Mount Etna, which is the only known source of Na-alkaline volcanism during the Late Quaternary in the Mediterranean region (e.g., Cristofolini and Romano, 1982; Coltelli et al., 2000; Branca et al., 2004). Although the geochemical correlation of PT0915-11 to the few described Etnean distal tephra deposits (e.g., Keller et al., 1978; Paterne et al., 1988, 2008; Wulf et al., 2004; Wagner et al., 2008; Sulpizio et al., 2009; Vogel et al., 2010) is obvious, its stratigraphic position between Y-6 and the ESR-dated shell layer $(73570 \pm 7740 \mathrm{yr}$; Table 1) does not allow a chronological correlation with known distal deposits (Fig. 4j).

Proximal deposits of Mount Etna can be divided into five stratigraphic units (from bottom to top Unit A-E; Coltelli et al., 2000; Del Carlo et al., 2004), with age determinations derived from radiocarbon dating of included charcoals and palaeosols (Kieffer, 1970; Guest et al., 1984; Chester et al., 1987; Coltelli et al., 2000) or from K/Ar dating of interbedded lavaflows (Gillot et al., 1994). Overall, Unit A describes the oldest pyroclastic unit ( $>100 \mathrm{ka}$ ) with basaltic to hawaiitic composition. Units B (100-80 ka) and D (15.5-15 ka) show benmoreitic to trachytic composition, while interbedded Unit C (80-16 ka) has a basaltic to mugearitic composition. The youngest unit, Unit E (13 ka-present), comprises basaltic deposits (Coltelli et al., 2000). The benmoreitic composition of PT0915-11 would correspond with Units B or D. Unit $\mathrm{D}$ can be excluded, as it is much too young for the stratigraphic position of PT0915-11. Likewise, Unit B is much too old, and no mass-wasting structures or erosional surfaces are reported in the lithological succession of core Co1215 from Lake Prespa (Wagner et al., 2012a). Reworking of tephra could have occurred and might explain a correlation with older eruptions (e.g., Boygle, 1999; Gudmundsdóttir et al.,
2011). However, PT0915-11 is fairly abundant in scoria fragments, it shows a well-defined peak in MS and a narrow cluster in geochemical compositions and, therefore, it is considered as in situ (primary) tephra derived from a single source. A correlation of PT0915-11 with Unit C is likely according to its stratigraphic position between Y-6 and the ESR-dated shell layer. The apparent geochemical mismatch is probably due to major unconformities and erosional surfaces in Unit $\mathrm{C}$ between ca. 80000 and $45000 \mathrm{yr}$ (Coltelli et al., 2000). A potential source of PT0915-11 could be the large caldera collapse, with the release of large volumes of benmoreitic pyroclastica, around $60000 \mathrm{yr}$ (Chester et al., 1985; Gillot et al., 1994), but the lack of robust data from proximal and distal deposits makes an unambiguous correlation of PT0915-11 with a known eruption of Mount Etna impossible at present.

\section{Core chronology and sedimentation rates}

Based on identified tephra and cryptotephra layers, radiocarbon ages, ESR dating and on comparison with marine as well as ice core records, a reliable stratigraphic and chronological framework can be constructed for core Co1215 from Lake Prespa (Fig. 10).

The uppermost part of core Co1215 is chronologically well constrained from radiocarbon dating and tephrostratigraphy (Fig. 10). Aufgebauer et al. (2012) discussed in detail the chronology of core Co1215 for the last 17000 cal yr BP. Overall, 10 radiocarbon dates and 2 tephras/cryptotephras define the Holocene sequence of core Co1215, which comprises the uppermost $2.04 \mathrm{~m}$. The Holocene sedimentation is characterised by high but fluctuating TIC and TOC, absence of ice rafted detritus (IRD) and a mean sedimentation rate of $0.13 \mathrm{~mm} \mathrm{yr}^{-1}$ (Fig. 10). The good age control is a precondition for the definition of short-term events in core Co1215, such as the 8.2 cooling event (Aufgebauer et al., 2012; Wagner et al., 2012a), and allows correlation with other datasets, such as the oxygen isotope dataset from NGRIP (North Greenland Ice Core Project members, 2004) based on the Greenland Ice Core Chronology 2005 (GICC05) time scale (GICC05modelext, 2010 and references therein) (Fig. 2).

The Pleistocene/Holocene transition is characterised by distinct changes in the lithology and by significant shifts in the pollen, which are related to short-term climate changes, such as Younger Dryas and Bölling/Alleröd (Aufgebauer et al., 2012; Panagiotopoulos et al., 2012). This transition is also well constrained by three radiocarbon dates and the pre-NYT deposits (Tufi Biancastri), which indicate that the Holocene/Pleistocene transition zone is located between 2.92-2.04 m depth (Fig. 2).

The shift from brownish to greyish sediments, the occurrence of IRD, and a significant drop in TOC and TIC below $2.92 \mathrm{~m}$ depth indicate sedimentation under cooler climate conditions, such as expected for Marine Isotope Stage 


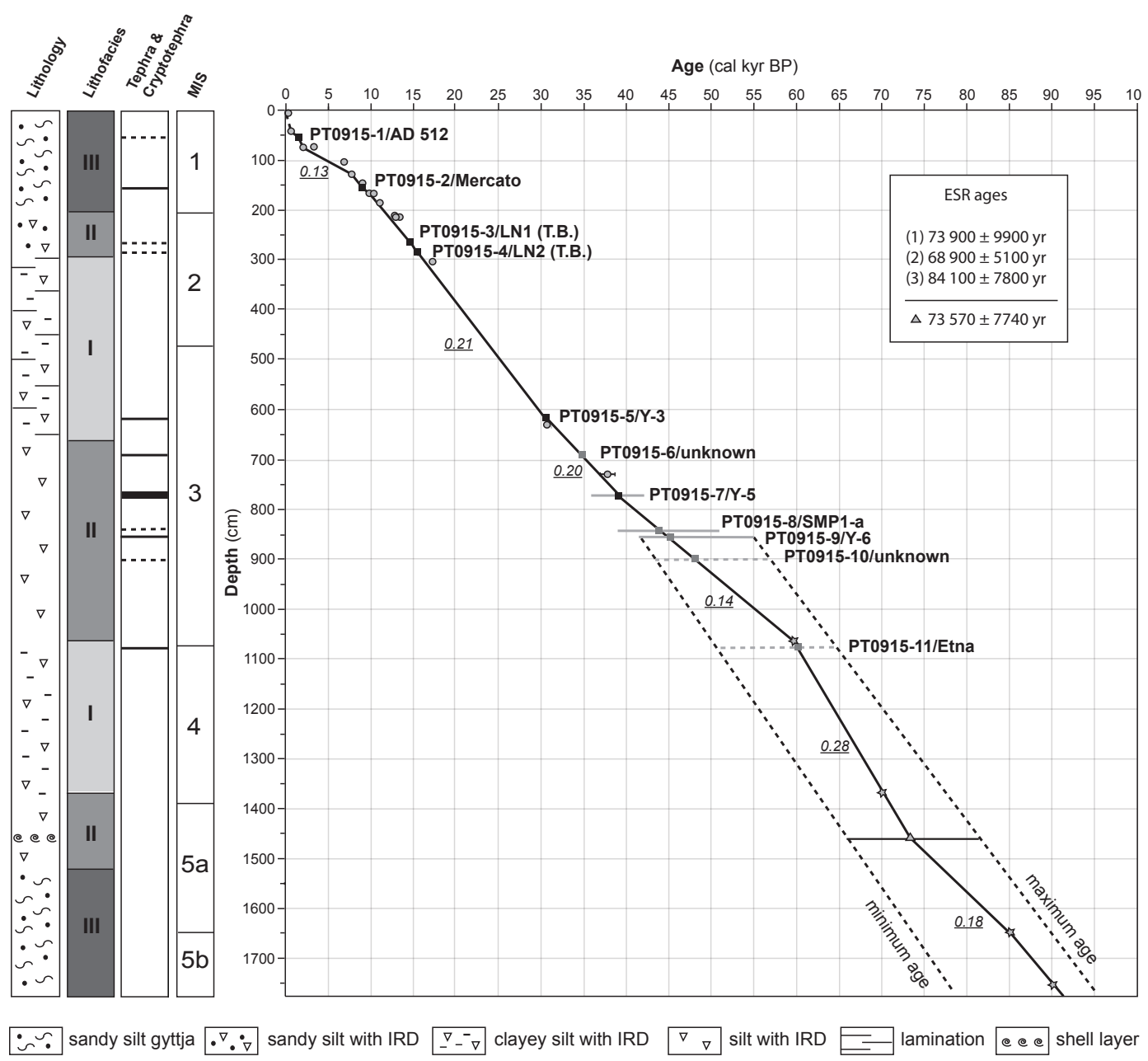

Fig. 10. Age-depth model and calculated sedimentation rates $\left(\mathrm{mm} \mathrm{yr}^{-1}\right)$ for the composite core Co1215 from Lake Prespa. Lithology, lithofacies, tephras and cryptotephras, marine isotope stages (MIS) 1-5 (Bassinot et al., 1994) are also shown. The age-depth model is based on tephrostratigraphy (black and grey squares), radiocarbon dates (grey circles), an error-weighted mean ESR age of a shell layer at 14.58$14.63 \mathrm{~m}$ depth (grey triangle), and tie points resulting from the correlation with the oxygen isotope dataset from NGRIP-GICC05 (grey stars) (Fig. 2). Chronological tie points were interpolated on a linear basis, whereby dotted black lines indicate maximum and minimum ages. Grey lines show literature age-ranges proposed for tephras and cryptoptephras, whereas dotted grey lines and grey squares represent age-ranges and ages developed within the presented age-depth model for tephras and cryptotephras.

(MIS) 2 (Bassinot et al., 1994). Age control in this part of the core is given by the plant remain from $3.03 \mathrm{~m}$ depth (Table $1 ; 17159 \pm 301 \mathrm{cal} \mathrm{yr} \mathrm{BP}$ ), and, further downcore, by tephra PT0915-5/Y-3 at $6.17 \mathrm{~m}$ depth and radiocarbon sample ETH-40064 from $6.33 \mathrm{~m}$ depth, indicating ages around 30000 and $31000 \mathrm{cal}$ yr BP. Based on these ages, a mean sedimentation rate of $0.21 \mathrm{~mm} \mathrm{r}^{-1}$ can be calculated for the upper lithofacies I or the period around the Last Glacial Maximum. An increased sedimentation rate at this period confirms earlier studies (Wagner et al., 2010) and can be explained by higher soil erosion during glacial periods due to the existence of local glaciers in the catchment (Belmecheri et al., 2009; Ribolini et al., 2011).

The sequence between 6.33 and $10.66 \mathrm{~m}$ depth comprises most of lithofacies II and chronologically constrained by five tephras/cryptotephras and one radiocarbon age. The well-defined PT0915-5/Y-3 tephra at $6.17 \mathrm{~m}$ depth and the PT0915-7/Y-5 tephra around $7.74 \mathrm{~m}$ depth suggest a mean sedimentation rate of $0.20 \mathrm{~mm} \mathrm{yr}^{-1}$ (Fig. 10), which is in good agreement with a radiocarbon age of $37760 \pm 808 \mathrm{cal} \mathrm{yr} \mathrm{BP}$ at $7.28 \mathrm{~m}$ depth (Table 1). According to linear interpolation between both tephras, tephra PT09156 , which could not be attributed to a specific source, has been deposited around $35000 \mathrm{cal} \mathrm{yr} \mathrm{BP.} \mathrm{The} \mathrm{slightly} \mathrm{decreased}$ sedimentation rate indicates slightly lower erosion and correlates with increased organic matter, such as observed during the Holocene and as it can be presumed for MIS 3. As the organic matter content is even higher beneath the Y-5, we suppose that the sedimentation rate is similar or even lower compared with the sequence between Y-3 and Y-5. Assuming 
that the decrease of TOC at $10.66 \mathrm{~m}$ depth corresponds to the onset of Dansgaard-Oeschger interstadial 17 at $59.4 \mathrm{kyr}$ in the oxygen isotope dataset from NGRIP-GICC05, a mean sedimentation rate of $0.14 \mathrm{~mm} \mathrm{yr}^{-1}$ can be calculated for the lithofacies II section below the Y-5. The calculated sedimentation rate suggests an age of ca. 44000 cal yr BP for cryptotephra PT0915-8/SMP1-a, which almost averages the age estimations provided by Di Vito et al. (2008) (Fig. 10). It would also provide an age of ca. $45000 \mathrm{cal} \mathrm{yr}$ BP for tephra PT0915-9/Y-6, which matches well with the age suggested by Keller et al. (1978) and the minimum ages suggested by Cornette et al. (1983), Civetta et al. (1984) and Mahood and Hildreth (1986). An age of ca. 48500 cal yr BP can be proposed for cryptotephra PT0915-10, which is of an unknown origin so far (Fig. 10).

The chronology of the sequence below $10.66 \mathrm{~m}$ depth in core Co1215 is less well constrained. The only independent chronological tie point in this part of the core comes from the ESR dating of a shell layer at $14.58-14.63 \mathrm{~m}$ depth, which provided a mean age of $73570 \pm 7740 \mathrm{yr}$ (Table 1). Linear interpolation between the presumed age of $59.5 \mathrm{kyr}$ at $10.66 \mathrm{~m}$ depth and the ESR-dated horizon implies a mean sedimentation rate of $0.28 \mathrm{~mm} \mathrm{yr}^{-1}$ and an age of ca. 60000 cal yr BP for tephra PT0915-11 (Fig. 10), which was attributed to an unknown eruption of Mount Etna. The relatively high sedimentation rate corresponds with low organic matter content and increased erosion, such as presumed for full glacial conditions during MIS 4. The sedimentation rate and the age-depth curve are supported by an increase of TOC at $13.70 \mathrm{~m}$ depth, which can be correlated with the end of Dansgaard-Oeschger interstadial 19 around $70 \mathrm{kyr}$ in the oxygen isotope dataset from NGRIP-GICC05 (Fig. 2).

The chronology of the core section below the ESR-dated shell layer cannot be defined by independent chronological tie points. However, the lithology and increasing TOC to values similar to those of the Holocene (Fig. 2) imply that the lowermost part of the core was deposited during warmer climate of MIS 5. Peaks in TOC at 16.38 and $17.56 \mathrm{~m}$ depth can be correlated with Dansgaard-Oeschger interstadials 21 and 22 and, therefore, to ages of ca. 85 and $90 \mathrm{kyr}$, respectively (Figs. 2 and 10). Overall, the sedimentation rate through this section of the core can be calculated to $0.18 \mathrm{~mm} \mathrm{yr}^{-1}$ (Fig. 10). Extrapolation of this sedimentation rate provides an age of ca. $91000 \mathrm{cal} \mathrm{yr} \mathrm{BP}$ for the core base. A basal age of $<100$ cal kyr BP corresponds well with the tephrostratigraphy observed from Lake Ohrid. In sediment sequences from this lake, three tephras of $>100 \mathrm{cal} \mathrm{kyr} \mathrm{BP}$ were found (X-5, $101.6 \mathrm{kyr}$; X-6, $108.4 \mathrm{kyr}$; P-11, $131 \mathrm{kyr}$; Vogel et al., 2010), which were not observed in core Co1215 from Lake Prespa.

The comparison of core Co1215 with sediment records from Lake Ohrid indicates that sedimentation rates in both lakes during glacial and interglacial conditions are different (Caron et al., 2010; Lézine et al., 2010; Vogel et al., 2010). While the records from Lake Ohrid indicate higher sedimentation rates during interglacials compared to glacial periods, core Co1215 from Lake Prespa shows contrary sedimentation conditions. A possible explanation is the difference in the catchment. Lake Ohrid is mainly fed by water from karst aquifers, whereas the small streams feeding Lake Prespa originate in a geologically diverse catchment (Matzinger et al., 2006). For Lake Ohrid, the water from the surrounding limestone mountain ranges (Popovska and Bonacci, 2007) is rich in $\mathrm{Ca}^{2+}$ and $\mathrm{HCO}_{3}^{-}$ions and triggers carbonate precipitation in the lake during warm periods. The carbonate content during these periods can be up to $80 \%$ of the total sediments (Wagner et al., 2008) and, therefore, increases the sedimentation rate significantly. In contrast, sedimentation rates in Lake Prespa apparently are more controlled by vegetation cover and erosion changes in the catchment (Aufgebauer et al., 2012).

\section{Conclusions}

The study of a sediment core Co1215 from Lake Prespa and the correlation with other records, including Lake Ohrid, improves the tephrostratigraphy of the Balkans. Eleven tephra and cryptotephra layers were recognised, nine of which could be attributed to Italian volcanic activities during the Late Pleistocene and Holocene. The majority of the identified tephras and cryptotephras was produced by Campanian volcanoes, particularly Campi Flegrei, Somma-Vesuvius and Ischia Island, and are mostly well constrained in terms of their chronology (PT0915-1/AD512; PT0915-2/Mercato; PT0915-3 and PT0915-4/both Tufi Biancastri; PT0915-5/Y3; PT0915-7/Y-5; PT0915-8/SMP1-a). The age range of SMP1-a is wide, but according to our age-depth model PT0915-8 would have been deposited at $44000 \mathrm{cal} \mathrm{yr} \mathrm{BP}$. Two tephras have been assigned to eruptions of Pantelleria Island (PT0915-9/Y-6) and Mount Etna (PT091511/unknown) and attain, according to our age-depth model, the ages of 45000 and $60000 \mathrm{cal} \mathrm{yr} \mathrm{BP,} \mathrm{respectively.} \mathrm{Two}$ tephras, PT0915-6 and PT0915-10, which remain unidentified at present, were deposited at 35000 and $48500 \mathrm{cal} \mathrm{yr} \mathrm{BP,}$ respectively.

The recognised tephras and cryptotephras are important stratigraphic marker horizons for palaeoclimatological studies on the lake. Moreover, they improve the knowledge of tephra dispersal patterns and past wind patterns in the Mediterranean. Inhomogeneous distribution patterns of tephra, i.e., Y-6/Green Tuff, give valuable information about a complex tephra dispersal resulting from interplay of different wind patterns, i.e., the Westerlies and the Scirocco winds from the South. The search for cryptotephras by means of MS and XRF scanning and microscopic screening is substantial for establishing a reliable tephrostratigraphical record. A well-defined tephrochronological record is valuable for linking marine/terrestrial records and archaeological sequences chronologically. This is an important precondition for a 
better understanding of the motivation and driving factors of early hominids migration from Africa to Europe. On the other hand, the finding of tephras and cryptotephras in archeological sites and sedimentological records is indispensable for the reconstruction of tephra dispersal.

\section{Supplementary material related to this article is available online at: http://www.clim-past.net/9/267/2013/ cp-9-267-2013-supplement.zip.}

Acknowledgements. The study was funded by the German Research Foundation (DFG) and forms part of project B2 of the CRC 806 "Our Way to Europe - Culture-Environment Interaction and Human Mobility in the Late Quaternary". We would like to thank our colleagues at the Hydrobiological Institute in Ohrid for logistic support during the field campaigns in 2007, 2009 and 2011. We thank the PRIN2009 project (R. Sulpizio) for their support at the University of Pisa, Italy. R. Santacroce and S. Wulf are greatly acknowledged for revising the manuscript and constructive comments.

Edited by: K.Reicherter

\section{References}

Alessio, M., Bella, F., Improta, S., Belluomini, G., and Cortesi, C.: University of Rome carbon-14 dates IX, Radiocarbon, 13, 395411, 1971.

Andronico, D.: La Stratigrafia dei prodotti dell'eruzione di Lagno Amendolare (Phlegrean Fields, Napoli), Atti. Soc. Toscana Sci. Nat., Mem., Serie A, 104, 165-178, 1997.

Aufgebauer, A., Panagiotopoulos, K., Wagner, B., Schaebitz, F., Viehberg, F. A., Vogel, H., Zanchetta, G., Sulpizio, R., Leng, M. J., and Damaschke, M.: Climate and environmental change in the Balkans over the last $17 \mathrm{ka}$ recorded in sediments from Lake Prespa (Albania/F.Y.R. of Macedonia/Greece), Quatern. Int., 274, 122-135, 2012.

Avanzinelli, R., Bindi, L., Menchetti, S., and Conticelli, S.: Crystallization and genesis of peralkaline magmas from Pantelleria volcano, Italy: An integrated petrological and crystal-chemical study, Lihos, 73, 41-69, 2004.

Ayuso, R. A., De Vivo, B., Rolandi, G., Seal, R. R., and Paone, A.: Geochemical and isotopic $(\mathrm{Nd}-\mathrm{Pb}-\mathrm{Sr}-\mathrm{O})$ variations bearing on the genesis of volcanic rocks from Vesuvius, Italy, J. Volcanol. Geoth. Res., 82, 53-78, 1998.

Bassinot, F. C., Labeyrie, L. D., Vincent, E., Quidelleur, X., Shackleton, N. J., and Lancelot, Y.: The astronomical theory of climate and the age of the Brunhes-Matuyama magnetic reversal, Earth Planet. Sc. Lett., 126, 91-108, 1994.

Belmecheri, S., Namiotko, T., Robert, C., von Grafenstein, U., and Danielopol, D. L.: Climate controlled ostracods preservation in Lake Ohrid (Albania, Macedonia), Palaeogeogr. Palaeocl., 277, 236-245, 2009.

Bourne, A. J., Lowe, J. J., Trincardi, F., Asioli, A., Blockley, S. P. E., Wulf, S., Matthews, I. P., Piva, A., and Vigliotti, L.: Distal tephra record for the last ca. 105,000 years from the core PRAD 1-2 in the central Adriatic Sea: implications for marine tephrostratigraphy, Quaternary Sci. Rev., 29, 3079-3094, 2010.

Boygle, J.: Variability of tephra in lake and catchment sediments, Svinavatn, Iceland, Global Planet. Change, 21, 129-149, 1999.

Branca, S., Coltelli, M., and Groppelli, G.: Geological evolution of Etna volcano, in: Mt. Etna, edited by: Bonaccorso, A., Calvari, S., Coltelli, M., Del Negro, C., and Falsaperla, S., Volcano Laboratory, Geoph. Monog., Series 143, American Geophysical Union, Washington, DC, 49-63, 2004.

Calanchi, N. and Dinelli, E.: Tephrostratigraphy for the last $170 \mathrm{ka}$ in sedimentary successions from the Adriatic Sea, J. Volcanol. Geoth. Res., 177, 81-95, 2008.

Calanchi, N., Cattaneo, A., Dinelli, E., Gasparotto, G., and Lucchini, F.: Tephra layers in Late Quaternary sediments of the central Adriatic Sea, Mar. Geol., 149, 191-209, 1998.

Caron, B., Siani, G., Paterne, M., Santacroce, R., Sulpizio, R., and Zanchetta, G.: Land-sea correlation paleoclimatic records using tephra layers: The case of Sapropel S1 in Central Mediterranean, in: Oxygen Isotopes as Tracers of Mediterranean Climate Variability, Linking Past, Present and Future, edited by: Roberts, N., Zanchetta, G., and Jones, M., ESF MedCLIVAR workshop, 1113 June 2008, University of Pisa, p. 36, 2008.

Caron, B., Sulpizio, R., Zanchetta, G., Siani, G., and Santacroce, R.: The Late Holocene to Pleistocene tephrostratigraphic record of Lake Ohrid (Albania), Cr. Geosci., 342, 453-466, 2010.

Chester, D. K., Duncan, A. M., Guest, J. E., and Kilburn, C. R. J. (Eds.): Mount Etna, The anatomy of a volcano, Chapman and Hall London, 1-404, 1985.

Chester, D. K., Duncan, A. M., and Guest, J. E.: The pyroclastic deposits of Mount Etna volcano, Sicily, Geol. J., 22, 225-243, 1987.

Cioni, R., Marianelli, P., and Santacroce, R.: Thermal and compositional evolution of the shallow magma chambers of Vesuvius: evidence from pyroxene phenocrysts and melt inclusions, J. Geophys. Res., 103, 18277-18294, 1997.

Cioni, R., Bertagnini, A., Andronico, D., Cole, P. D., and Mundula, F.: The $512 \mathrm{AD}$ eruption of Vesuvius: Complex dynamics of a small scale subplinian event, B. Volcanol., 73, 789-810, 2011.

Civetta, L., Cornette, Y., Crisci, G., Gillot, P. Y., Orsi, G., and Requejo, C. S.: Geology, geochronology and chemical evolution of the island of Pantelleria, Geol. Mag., 121, 541-562, 1984.

Civetta, L., Cornette, Y., Gillot, P. Y., and Orsi, G.: The eruptive history of Pantelleria (Sicily Channel) in the last $50 \mathrm{ka}, \mathrm{B}$. Volcanol., 50, 47-57, 1988.

Civetta, L., Orsi, G., Pappalardo, L., Fisher, R. V., Heiken, G., and Ort, M.: Geochemical zoning, mingling, eruptive dynamics and depositional processes - the Campanian Ignimbrite, Campi Flegrei caldera, Italy, J. Volcanol. Geoth. Res., 75, 183-219, 1997.

Coltelli, M., Del Carlo, P., and Vezzoli, L.: Stratigraphic constrains for explosive activity in the past $100 \mathrm{ka}$ at Etna volcano, Italy, Int. J. Earth Sci., 89, 665-677, 2000.

Cornette, Y., Crisci, G. M., Gillot, P. Y., and Orsi, G.: The recent volcanic history of Pantelleria: a new interpretation, J. Volcanol. Geoth. Res., 17, 361-373, 1983.

Crisci, G. M., De Francesco, A. M., Mazzuoli, M., Poli, G., and Stanzione, D.: Geochemestry of recent volcanics of Ischia Island, Italy: Evidences for fractional crystallization and magma mixing, Chem. Geol., 78, 15-33, 1989. 
Cristofolini, R. and Romano, R.: Petrologic features of the Etnean volcanic rocks, Mem. Soc. Geol. It., 23, 323-336, 1982.

De Vivo, B., Rolandi, G., Gans, P. B., Calvert, A., Bohrson, W. A., Spera, F. J., and Belkin, H. E.: New constraints on the pyroclastic eruptive history of the Campanian volcanic plain (Italy), Miner. Petrol., 73, 47-65, 2001.

Del Carlo, P., Vezzoli, L., and Coltelli, M.: Last 100 ka Tephrostratigraphic record of Mount Etna, in: Mt. Etna, edited by: Bonaccorso, A., Geoph. Monog., Series 143, Volcano Laboratory, American Geophysical Union, Wahington, DC, 77-89, 2004.

Deino, A. L., Southon, J., Terrasi, F., Campajola, L., and Orsi, G.: ${ }^{14} \mathrm{C}$ and ${ }^{40} \mathrm{Ar} /{ }^{39} \mathrm{Ar}$ Dating of the Campanian Ignimbrite, Phlegran Fields, Italy, ICOG Abstracts, Berkeley, CA, USA, 1994.

Deino, A. L., Orsi, G., de Vita, S., and Piochi, M.: The age of the Neapolitan Yellow Tuff caldera-forming eruption (Campi Flegrei caldera e Italy) assessed by ${ }^{40} \mathrm{Ar} /{ }^{39} \mathrm{Ar}$ dating method, J. Volcanol. Geoth. Res., 133, 157-170, 2004.

Di Vito, M., Sulpizio, R., Zanchetta, R., and D'Orazio, M.: The late Pleistocene pyroclastic deposits of the Campanian Plain: new insights on the explosive activity of Neapolitan volcanoes, J. Volcanol. Geoth. Res., 177, 19-48, 2008.

Druitt, T. H., Brenchley, P. J., Gökten, Y. E., and Francaviglia, V.: Late Quaternary rhyolitic eruptions from the Acıgöl Complex, central Turkey, J. Geol. Soc., 152, 655-667, 1995.

Fedele, F. G., Giaccio, B., Isaia, R., and Orsi, G.: The Campanian Ignimbrite eruption, Heinrich event 4 and the Palaeolithic change in Europe: a high-resolution investigation, in: Volcanism and Earth's Atmosphere, edited by: Robock, A. and Oppenheimer, C., Geoph. Monog. 139, Washington, USA, 301-325, 2003.

Fedele, F. G., Giaccio, B., Isaia, R., Orsi, G., Carroll, M., and Scaillet, B.: The Campanian Ignimbrite factor: towards a reappraisal of the Middle to Upper Palaeolithic transition, in: Living Under the Shadow; the Cultural Impacts of Volcanic Eruptions, edited by: Grattan, J. and Torrence, R., One World Archaeol. 53, Left Coast Press, California, 19-41, 2007.

Fedele, F. G., Giaccio, B., and Hajdas, I.: Timescales and cultural process at 40,000 BP in the light of the Campanian Ignimbrite eruption, Western Eurasia, in: Setting the Record Straight: Toward a Systematic Chronological Understanding of the Middle to Upper Paleolithic Boundary in Eurasia, edited by: Adler, D. S. and Jöris, O., J. Hum. Evol., 55, 834-857, 2008.

Geological Maps of Yugoslavia (Ed. Geological Institute Belgrade): Maps 1:100 000, sheets K34-114 Podgradec, K34-102 Ohrid, K34-103 Bitola, K34-115 Lerin, Geological Institute Belgrade, 1977.

Giaccio, B., Hajdas, I., Peresani, M., Fedele, F. G., and Isaia, R.: The Campanian Ignimbrite and its relevance for the timing of the Middle to Upper Palaeolithic shift, in: When Neanderthals and Modern Humans Met, Publications in Prehistory, edited by: Conard, N. J., Kerns Verlag, Tübingen, 343-375, 2006.

Giaccio, B., Isaia, R., Fedele, F. G., Di Canzio, E., Hoffecker, J., Ronchitelli, A., Sinitsyn, A., Anikovich, M., and Lisitsyn, S. N.: The Campanian Ignimbrite and Codola tephra layers: two temporal/stratigraphic markers for the Early Upper Palaeloithic in southern Italy and eastern Europe, J. Volcanol. Geoth. Res., 177, 208-226, 2008.

Giaccio, B., Messina, P., Sposato, A., Votaggio, M., Zanchetta, G., Galadini, F., Gori, S., and Santacroce, R.: Tephra layers from Holocene lake sediments of the Sulmona Basin, Central Italy: implications for volcanic activity in Peninsular Italy and tephrostratigraphy in the central Mediterranean area, Quaternary Sci. Rev., 28, 2710-2733, 2009.

GICC05modelext, available at: http://www.iceandclimate.nbi.ku. dk/data/ (last access: 28 January 2013), 2010.

Gillot, P. Y., Kieffer, G., and Romano, R.: The evolution of Mount Etna in the light of potassium-argon dating, Acta Vulc., 5, 81-87, 1994.

Grün, R.: Electron Spin Resonance (ESR) dating, Quatern. Int., 1, 65-109, 1989.

Gudmundsdóttir, E. R., Eiríksson, J., and Larsen, G.: Identification and definition of primary and reworked tephra in Late glacial and Holocene marine shelf sediments off North Iceland, J. Quaternary Sci., 26, 589-602, 2011.

Guest, J. E., Chester, D. K., and Duncan, A. M.: The Valle del Bove, Mount Etna: its origin and relation to the stratigraphy and structure of the volcano, J. Volcanol. Geoth. Res., 26, 384-387, 1984.

Hoffmann, P.: Non-Invasive Identification of Chemical Compounds by EDXRS, in: Handbook of Practical X-ray Fluorescence Analysis, edited by: Beckhoff, B., Kanngießer, B., Langhoff, N., Wedell, R., and Wolff, H., Springer-Verlag, Berlin Heidelberg, Germany, 769-783, 2006.

Jahns, S. and van den Boogard, C.: New palynological and tephrostratigraphical investigations of two salt lagoons on the island of Mljet, south Dalmatia, Croatia, Veg. Hist. Archaeobot., 7, 219234, 1998.

Keller, J., Ryan, W. B. F., Ninkovich, D., and Altherr, R.: Explosive volcanic activity in the Mediterranean over the past 200,000 $\mathrm{yr}$ as recorded in deep-sea sediments, Geol. Soc. Am. Bull., 89, 591604, 1978.

Keller, J., Rehren, T., and Stadkbauer, E.: Explosive volcanism in the Hellenic Arc; a summary and review, in: Thera and the Aegean World III, edited by: Hardy, D. A., Keller, J., Galanopoulos, V. P., Flemming, N. C., and Druitt, T. H., Thera Foundation Santorini, Greece, 13-26, 1990.

Kieffer, G.: Un ultime phase d'activiti de la Valle del bove (Etna), Cr. Acad. Sci. Paris, 270, 3198-3201, 1970.

Lane, C., Andric, M., Cullen, V., and Blockley, S. P. E.: The occurrence of distal Icelandic and Italian tephra in the Lateglacial of Lake Bled, Slovenia, Quaternary Sci. Rev., 30, 1013-1018, 2011a.

Lane, C., Barker, G., Reynolds, T., Inglis, R., Barton, N., Albert, P., and Tomlinso, E.: Dating the Palaeolithic occupation of the Haua Fteah cave, Libya, using cryptotephrochronology, XVIII INQUA Congress, Quaternary Sciences - the view from the mountains, 21-27 July 2011, Bern, Switzerland, 2011b.

Le Bas, M. J., Le Maitre, R. W., Streckeisen, A., and Zanettin, B.: A chemical classification of volcanic rocks based on the total alkali-silica diagram, J. Petrol., 27, 745-750, 1986.

Levin, I. and Kromer, B.: The tropospheric ${ }^{14} \mathrm{CO}_{2}$ level in midlatitudes of the Northern Hemisphere (1959-2003), Radiocarbon, 46, 1261-1272, 2004.

Lézine, A. M., von Grafenstein, U., Andersen, N., Belmecheri, S., Bordon, A., Caron, B., Cazet, J. P., Erlenkeuser, H., Fouache, E., Grenier, C., Huntsman-Mapila, P., Hureau-Mazaudier, D., Manelli, D., Mazaud, A., Robert, C., Sulpizio, R., Tiercelin, J. J., Zanchetta, G., and Zeqollari, Z.: Lake Ohrid, Albania, provides an exceptional multi-proxy record of environmental changes during the last glacial-interglacial cycle, Palaeogeogr. Palaeocl., 
287, 116-127, 2010.

Lindhorst, K., Vogel, H., Krastel, S., Wagner, B., Hilgers, A., Zander, A., Schwenk, T., Wessels, M., and Daut, G.: Stratigraphic analysis of lake level fluctuations in Lake Ohrid: an integration of high resolution hydro-acoustic data and sediment cores, Biogeosciences, 7, 3531-3548, doi:10.5194/bg-7-3531-2010, 2010.

Lowe, J. J., Blockley, S. P. E., Trincardi, F., Asioli, A., Cattaneo, A., Matthews, I. P., Pollard, A. M., and Wulf, S.: Age modelling of late Quaternary marine sequences in the Adriatic: towards improved precision and accuracy using volcanic event stratigraphy, Cont. Shelf. Res., 27, 560-582, 2007.

Macdonald, R.: Nomenclature and petrochemistry of the peralkaline oversaturated extrusive rocks, B. Volcanol., 38, 498-516, 1974.

Mahood, G. A. and Hildreth, W.: Geology of the peralkaline volcano at Pantelleria, Strait of Sicily, B. Volcanol., 48, 143-172, 1986.

Marianelli, P. and Sbrana, A.: Risultati di misure di standard di minerali e di vetri naturali in microanalisi a dispersione di energia, Atti. Soc. Toscana Sci. Nat., Mem., Serie A, 105, 57-63, 1998.

Matzinger, A., Jordanoski, M., Veljanoska-Sarafiloska, E., Sturm, M., Müller, B., and Wüest, A.: Is Lake Prespa jeopardizing the ecosystem of ancient Lake Ohrid?, Hydrobiologia, 553, 89-109, 2006.

Mele, D., Sulpizio, R., Dellino, P., and La Volpe, L.: Stratigraphy and eruptive dynamics of a pulsating Plinian eruption of SommaVesuvius: the Pomici di Mercato (8900 years BP), B. Volcanol., 73, 257-278, 2011.

Morley, M. W. and Woodward, J. C.: The Campanian Ignimbrite (Y5) tephra at Crvena Stijena Rockshelter, Montenegro, Quaternary Res., 75, 683-696, 2011.

Munno, R. and Petrosino, P.: The late Quaternary tephrostratigraphical record of the San Gregorio Magno basin (southern Italy), J. Quaternary Sci., 22, 247-266, 2007.

Narcisi, B.: Tephrochronology of a Late Quaternary lacustrine record from the Monticchio Maar, Vulture volcano, Southern (Italy), Quaternary Sci. Rev., 15, 155-165, 1996.

Narcisi, B. and Vezzoli, L.: Quaternary stratigraphy of distal tephra layers in the Mediterranean - an overview, Global Planet. Change, 21, 31-50, 1999.

North Greenland Ice Core Project members: High-resolution record of Northern Hemisphere climate extending into the last interglacial period, Nature, 431, 147-151, 2004.

Orsi, G. and Sheridan, M. F.: The green Tuff of Pantelleria: a rheoignimbrite or rheomorphic fall?, B. Volcanol., 47, 611-626, 1984.

Orsi, G., Gallo, G., Heiken, G., Wohletz, K., Yu, E., and Bonani, G.: A comprehensive study of pumice formation and dispersal: the Cretaio Tephra of Ischia (Italy), J. Volcanol. Geoth. Res., 53, 329-354, 1992.

Orsi, G., Civetta, L., D’Antonio, M., Di Girolamo, P., and Piochi, M.: Step-filling and development of a three-layers magma chamber: the Neapolitan Yellow Tuff case history, J. Volcanol. Geoth. Res., 67, 291-312, 1995.

Orsi, G., de Vita, S., and Di Vito, M.: The restless, resurgent Campi Flegrei nested caldera (Italy): constraints on its evolution and configuration, J. Volcanol. Geoth. Res., 74, 179-214, 1996.
Pabst, S., Wörner, G., Civetta, L., and Tesoro, R.: Magma chamber evolution prior to the Campanian Ignimbrite and Neapolitan Yellow Tuff eruptions (Campi Flegrei, Italy), B. Volcanol., 70, 961-976, 2008.

Panagiotopoulos, K., Aufgebauer, A., Schäbitz, F., and Wagner, B.: Vegetation and climate history of Lake Prespa since the Lateglacial, Quatern. Int., doi:10.1016/j.quaint.2012.05.048, in press, 2012.

Pappalardo, L., Civetta, L., D’Antonio, M., Deino, A., Di Vito, M. A., Orsi, G., Carandente, A., de Vita, S., Isaia, R., and Piochi, M.: Chemical and $\mathrm{Sr}$ - isotopic evolution of the Phlegrean magmatic system before the Campanian Ignimbrite and the Neapolitan Yellow Tuff eruptions, J. Volcanol. Geoth. Res., 91, 141-166, 1999.

Paterne, M.: Reconstruction de l'activité explosive des volcans de l'Italie du Sud par tephrochronologie marine, Thèse DoctoratEtat, Université Paris-Sud, Orsay, 1-141, 1985.

Paterne, M.: Additional remarks on tephra layers from Temnata Cave, in: Temnata Cave - Excavations in Karlukovo Karst Area, Bulgaria, edited by: Kozlowski, J. K., Laville, H., and Ginter, B., Jagellonian University Press, Krakow, 99-100, 1992.

Paterne, M., Guichard, F., and Labeyrie, J.: Explosive activity of the south Italian volcanoes during the past 80,000 years as determined by marine tephrochronology, J. Volcanol. Geoth. Res., 34, 153-172, 1988.

Paterne, M., Kallel, N., Labeyrie, L., Vautravers, M., Duplessy, J. C., Rossignol-Strick, M., Cortijo, E., Arnold, M., and Fontugne, M.: Hydrological relationship between the North Atlantic Ocean and the Mediterranean Sea during the past $15-75 \mathrm{kyr}$, Paleoceanography, 14, 626-638, 1999.

Paterne, M., Guichard, F., Duplessy, J. C., Siani, G., Sulpizio, R., and Labeyrie, J.: A 90,000-200,000 yrs marine tephra record of Italian volcanic activity in the central Mediterranean Sea, J. Volcanol. Geoth. Res., 177, 187-196, 2008.

Peccerillo, A.: Plio-Quaternary volcanism in Italy. Petrology Geochemistry Geodynamics, Springer, Heidelberg, 1-365, 2005.

Poli, S., Chiesa, S., Gillot, P. Y., Gregnanin, A., and Guichard, F.: Chemistry versus time in the volcanic complex of Ischia (Gulf of Naples, Italy): evidence of successive magmatic cycles, Contrib. Mineral. Petr., 95, 322-335, 1987.

Popovska, C. and Bonacci, O.: Basic data on the hydrology of Lakes Ohrid and Prespa, Hydrol. Process., 21, 658-664, 2007.

Pyle, D. M., Ricketts, G. D., Margari, V., van Andel, T. H., Sinitsyn, A. A., Praslov, N. D., Nicolai, D., and Lisitsyn, S.: Wide dispersal and deposition of distal tephra during the Pleistocene Campanian Ignimbrite/Y5 eruption, Italy, Quaternary Sci. Rev., 25, 27132728, 2006.

Reimer, P. J., Baillie, M. G. L., Bard, E., Bayliss, A., Beck, J. W., Bertrand, C., Blackwell, P. G., Buck, C. E., Burr, G., Cutler, K. B., Damon, P. E., Edwards, R. L., Fairbanks, R. G., Friedrich, M., Guilderson, T. P., Hughen, K. A., Kromer, B., McCormac, F. G., Manning, S., Bronk Ramsey, C., Reimer, R. W., Remmele, S., Southon, J. R., Stuiver, M., Talamo, S., Taylor, F. W., van der Plicht, J., and Weyhenmeyer, C. E.: Intcal04 terrestrial radiocarbon age calibration, 0-26 cal ky BP, Radiocarbon, 46, 10291058, 2004.

Reimer, P. J., Baillie, M. G. L., Bard, E., Bayliss, A., Beck, J. W., Blackwell, P. G., Bronk Ramsey, C., Buck, C. E., Burr, G. S., Edwards, R. L., Friedrich, M., Grootes, P. M., Guilderson, T. P., Hajdas, I., Heaton, T. J., Hogg, A. G., Hughen, K. A., Kaiser, K. 
F., Kromer, B., McCormac, F. G., Manning, S. W., Reimer, R. W., Richards, D. A., Southon, J. R., Talamo, S., Turney, C. S. M., van der Plicht, J., and Weyhenmeyer, C. E.: IntCal09 and Marine09 radiocarbon age calibration curves, $0-50,000$ years cal BP, Radiocarbon, 51, 1111-1150, 2009.

Rethemeyer, J. , Dewald, A., Fülöp, R., Hajdas, I., Höfle, S., Patt, U., Stapper, B., and Wacker, L.: Status report on sample preparation facilities for ${ }^{14} \mathrm{C}$ analysis at the new CologneAMS centre, Nucl. Instrum. Meth. B., 294, 168-172, doi:10.1016/j.nimb.2012.02.012, 2013.

Ribolini, A., Isola, I., Zanchetta, G., Bini, M., and Sulpizio, R.: Glacial features on the Galicica Mountains, Macedonia, Preliminary report, Geogr. Fis. Din. Quat., 34, 247-255, 2011.

Riede, F., Bazely, B., Newton, A., and Lane, C.: A Laacher Seeeruption supplement to Tephrabase: Investigating distal tephra fallout dynamics, Quatern. Int., 246, 134-144, 2011.

Rosi, M. and Santacroce, R.: The A.D. 472 "Pollena" eruption: volcanological and petrological data for this poorly-known, Pliniantype event at Vesuvius, J. Volcanol. Geoth. Res., 17, 249-271, 1983.

Rosi, M. and Sbrana, A.: The Phlegraean Fields, CNR, Quad. Ric. Sci., 114, 1-175, 1987.

Santacroce, R.: Somma-Vesuvius, Quad. Ric. Sci., CNR-Roma, 114, 230 pp., 1987.

Santacroce, R., Cioni, R., Marianelli, P., Sbrana, A., Sulpizio, R., Zanchetta, G., Donahue, D., and Joron, J. L.: Age and whole rock-glass compositions of proximal pyroclastics from the major esplosive eruption of Somma-Vesuvius: a review as a tool for distal tephrostratigraphy, J. Volcanol. Geoth. Res., 177, 1-18, 2008.

Scarpati, C., Cole, P., and Perotta, A.: The Neapolitan Yellow Tuff a large volume multiphase eruption from Campi Flegrei, Southern Italy, B. Volcanol., 55, 343-356, 1993.

Schellmann, G. and Kelletat, D.: Chronostratigraphische Untersuchungen litoraler und äolischer Formen und Ablagerungen an der Südküste von Zypern mittels ESR-Altersbestimmungen an Mollusken- und Landschneckenschalen, Essener Geographische Arbeiten, 32, 75-98, 2001.

Schellmann, G., Beerten, K., and Radtke, U.: Electron spin resonance (ESR) dating of Quaternary materials, Eiszeitalter und Gegenwart, J. Quaternary Sci., 57, 150-178, 2008.

Schmincke, H. U., Park, C., and Harms, E.: Evolution and environmental impacts of the eruption of Laacher See Volcano (Germany) 12,900 a BP, Quatern. Int., 61, 61-72, 1999.

Siani, G., Sulpizio, R., Paterne, M., and Sbrana, A.: Tephrostratigraphy study for the last $18,000{ }^{14} \mathrm{C}$ years in a deep-sea sediment sequence for the South Adriatic, Quaternary Sci. Rev., 23, 24852500, 2004.

Sinitsyn, A. A.: The most ancient sites of Kostenki in the context of the Initial Upper Paleolithic of northern Eurasia, in: The Chronology of the Aurignacian and of the Transitional Technocomplexes. Dating, Stratigraphies, Cultural Implications, edited by: Zilhao, J. and d'Errico, F., Proccedings of Symposium 6.1 of the XIV-th Congress of the UISPP 33, Trabalhos de Arqueologia, University of Liege, Belgium, 89-107, 2003.

Soficaru, A., Dobos, A., and Trinkaus, E.: Early modern humans from the Pestera Muierii, Baia de Fier, Romania, P. Natl. Acad. Sci. USA, 103, 17196-17201, 2006.
St. Seymour, K., Christanis, K., Bouzinos, A., Papazisimou, S., Papatheodorou, G., Moran, E., and Denes, G.: Tephrostratigraphy and tephrochronology in the Philippi peat basin, Macedonia, Northern Hellas (Greece), Quatern. Int., 121, 53-65, 2004.

Stuiver, M. and Reimer, P. J.: CALIB 6.1.0. http://calib.qub.ac.uk/ calib/ (last access: 2 November 2012), 2011.

Sulpizio, R., Zanchetta, G., Paterne, M., and Siani, G.: A review of tephrostratigraphy in central and southern Italy during the last 65 ka, Il. Quaternario, 16, 91-108, 2003.

Sulpizio, R., Mele, D., Dellino, P., and La Volpe, L.: A complex, subplinian-type eruption from low-viscosity, phonolitic to tephriphonolitic magma: The AD 472 (Pollena) eruption of SommaVesuvius (Italy), B. Volcanol., 67, 743-767, 2005.

Sulpizio, R., van Welden, A., Caron, B., and Zanchetta, G.: The Holocene tephrostratigraphy of Lake Shkodra (Albania and Montenegro), J. Quaternary Sci., 25, 633-650, 2009.

Sulpizio, R., Zanchetta, G., D’Orazio, M., Vogel, H., and Wagner, B.: Tephrostratigraphy and tephrochronology of lakes Ohrid and Prespa, Balkans, Biogeosciences, 7, 3273-3288, doi:10.5194/bg7-3273-2010, 2010.

Ton-That, T., Singer, B., and Paterne, M.: ${ }^{40} \mathrm{Ar} /{ }^{39}$ Ar dating of latest Pleistocene (41 ka) marine tephra in the Mediterranean Sea: implications for global climate records, Earth Planet. Sc. Lett., 184, 645-658, 2001.

Trinkaus, E., Milota, Ş., Rodrigo, R., Mircea, G., and Moldovan, O.: Early modern human cranial remains from the Peştera cu Oase, Romania, J. Hum. Evol., 45, 245-253, 2003.

Van den Boogard, P.: ${ }^{40} \mathrm{Ar} /{ }^{39} \mathrm{Ar}$ ages of sanidine phenocrysts from Laacher See Tephra (12,900 yr BP): Chronostratigraphic and petrological significance, Earth Planet. Sc. Lett., 133, 163174, 1995.

Vitaliano, C. J., Taylor, S. R., Farrand, W. R., and Jacobsen, T. W. Tephra layer in Franchthi cave, Peleponnesus, Greece, in: Tephra Studies, edited by: Self, S., and Sparks, R. S. J., Riedel, Dordrecht, 373-379, 1981.

Vogel, H., Zanchetta, G., Sulpizio, R., Wagner, B., and Nowaczyk, N.: A tephrostratigraphic record for the last glacial interglacial cycle from Lake Ohrid, Albania and Macedonia, J. Quaternary Sci., 25, 320-338, 2010.

Wagner, B., Sulpizio, R., Zanchetta, G., Wulf, S., Wessels, M., and Daut, G.: The last 40 ka tephrostratigraphic record of Lake Ohrid, Albania and Macedonia: a very distal archive for ash dispersal from Italian volcanoes, J. Volcanol. Geoth. Res., 177, 71-80, 2008.

Wagner, B., Vogel, H., Zanchetta, G., and Sulpizio, R.: Environmental change within the Balkan region during the past ca. $50 \mathrm{ka}$ recorded in the sediments from lakes Prespa and Ohrid, Biogeosciences, 7, 3187-3198, doi:10.5194/bg-7-3187-2010, 2010.

Wagner, B., Aufgebauer, A., Vogel, H., Zanchetta, G., Sulpizio, R., and Damaschke, M.: Late Pleistocene and Holocene contourite drift in Lake Prespa (Albania/F.Y.R. of Macedonia/Greece), Quatern. Int., 274, 112-121, 2012a.

Wagner, B., Francke, A., Sulpizio, R., Zanchetta, G., Lindhorst, K., Krastel, S., Vogel, H., Rethemeyer, J., Daut, G., Grazhdani, A., Lushaj, B., and Trajanovski, S.: Possible earthquake trigger for 6th century mass wasting deposit at Lake Ohrid (Macedonia/Albania), Clim. Past, 8, 2069-2078, doi:10.5194/cp-8-20692012, 2012b. 
Walter-Simonnet, A. V., Bossuet, G., Develle, A. L., Becgeot, C., Ruffaldi, P., Magny, M., Adatte, T., Rossy, M., Simonnet, J. P., Boutet, J., Zeiller, R., de Beaulieu, J. L., Vannière, B., Thivet, M., Millet, L., Regent, B., and Wackenheim, C.: Chronicle and distribution of lateglacial tephras in the vosges and Jura mountains, and the Swiss plateau, Quaternaire, 19, 117-132, 2008.

White, J. C., Parker, D. F., and Ren, M.: The origin of trachyte and pantellerite from Pantelleria, Italy: Insights from major element, trace element, and thermodynamic modeling, J. Volcanol. Geoth. Res., 179, 33-55, 2009.

Wulf, S.: Das tephrochronologische Referenzprofil des Lago Grande di Monticchio-Eine dettaillierte Stratigraphie des süditalienischen esplosive Vulkanismus der letzen 100.000 Jahre, Ph.D. thesis, SRT1/03, Univeristy of Postdam, Germany, 1-124, 2001.

Wulf, S., Kraml, M., Brauer, A., Keller, J., and Negendank, J. F. W.: Tephrochronology of the $100 \mathrm{ka}$ lacustrine sediment record of Lago Grande di Monticchio (southern Italy), Quatern. Int., 122, 7-30, 2004.

Wulf, S., Brauer, A., Mingram, J., Zolitschka, B., and Negendank, J. F. W.: Distal tephras in the sediments of Monticchio maar lakes, in: La geologia del Monte Vulture - Regione Basilicata, edited by: Principe, C., Bollettino della Societa Geologica Italiana, Dipartimento Ambiente, Territorio, Politiche della Sostenibilitä, Potenza, 105-122, 2006.

Wulf, S., Kraml, M., and Keller, J.: Towards a detailed distal tephrostratigraphy in the Central Mediterranean: the last 20,000 yrs record of Lago Grande di Monticchio, J. Volcanol. Geoth. Res., 177, 118-132, 2008.

Zanchetta, G., Di Vito, M. A., Fallick, A. E., and Sulpizio, R.: Stable isotopes of pedogenic carbonates from the Somma-Vesuvius area, southern Italy, over the past $18 \mathrm{kyr}$ : Paleoclimatic implications, J. Quaternary Sci., 15, 813-824, 2000.

Zanchetta, G., Sulpizio, R., Giaccio, B., Siani, G., Paterne, M., Wulf, S., and D'Orazio, M.: The Y-3 Tephra: a Last Glacial stratigraphic marker for the central Mediterranean basin, J. Volcanol. Geoth. Res., 177, 145-154, 2008.

Zanchetta, G., Sulpizio, R., Roberts, N., Cioni, R., Eastwood, W. J., Siani, G., Caron, B., Paterne, M., and Santocroce, R.: Tephprostratigraphy, chronology and climatic events of the Mediterranean basin during the Holocene: an overview, Holocene, 21, 33-52, 2011. 